\title{
MTT
}

Käyttöveden riittävyys ja laatu maatalouden suurissa tuotantoyksiköissä

Sanna Sorvala, Maarit Puumala ja Marja Lehto

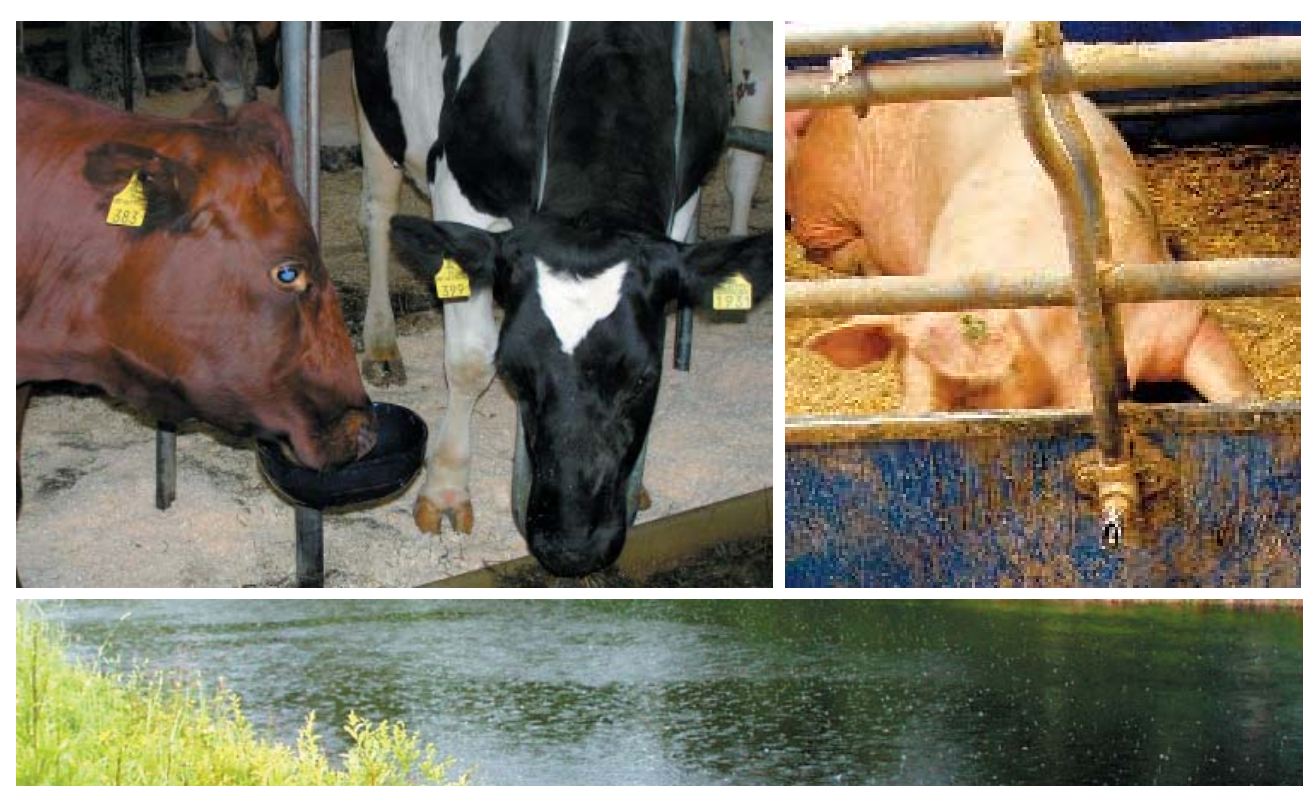

Teknologia 
MTT:n selvityksiä 108

$34 \mathrm{~s}$.

\section{Käyttöveden riittävyys ja laatu maatalouden suurissa tuotantoyksiköissä}

Sanna Sorvala, Maarit Puumala ja Marja Lehto 
ISBN 952-487-004-5 (Painettu)

ISBN 952-487-005-3 (Verkkojulkaisu)

ISSN 1458-509X (Painettu)

ISSN 1458-5103 (Verkkojulkaisu)

www.mtt.fi/mtts/pdf/mtts108.pdf

Copyright

MTT

Sanna Sorvala, Maarit Puumala ja Marja Lehto

Julkaisija ja kustantaja

MTT

Jakelu ja myynti

MTT, Kotieläintuotannon tutkimus, Vakolantie 55, 03400 Vihti

Puhelin (09) 224 251, telekopio (09) 2246210

Sähköposti: julkaisut@mtt.fi

Julkaisuvuosi

2006

Kannen kuvat

Jutta Kaihilahti ja Teemu Ala-Kleme

Painopaikka

Strålfors Information Logistics Oy 


\section{Käyttöveden riittävyys ja laatu maatalouden suurissa tuotantoyksiköissä}

Sanna Sorvala, Maarit Puumala ja Marja Lehto

MTT Maa- ja elintarviketalouden tutkimuskeskus, Kotieläintuotannon tutkimus, Vakolantie 55, 03400 Vihti, maarit.puumala@mtt.fi,marja.lehto@mtt.fi

\section{Tiivistelmä}

Tämän hankkeen tarkoituksena on ollut selvittää, mistä kotieläintilat saavat käyttövetensä sekä minkälaista on käyttöveden laatu. Hankkeessa on tarkasteltu sitä, miten kuivat jaksot ovat vaikuttaneet tilojen toimintaan, minkälaisia vedensäästötoimenpiteitä on toteutettu ja minkälaisiin toimenpiteisiin seuraavien kuivien jaksojen varalta on ryhdytty. Toisaalta on selvitetty erityisen märistä jaksoista mahdollisesti aiheutuneita ongelmia.

Kirjallisuustutkimuksessa selvitettiin maatalouden käyttöveden lähteet sekä veden juomaja pesuvesikäyttöä maatiloilla. Kaivoveden laatuun vaikuttaa maa- ja kallioperän koostumus sekä kaivon läheisyydessä olevat riskitekijät. Monet kallioperässä olevat alkuaineet, mm. rauta, fluori ja arseeni, voivat liueta veteen ja esiintyä myös kaivovedessä. Myös lähistöllä olevat pelto, maantie, eläinsuojat ja jätevesisäiliöt voivat vaikuttaa veden laatuun. Maatiloilla vettä kuluu eniten eläinten juomavedeksi. Eläintilojen pesussa käytetään liikuteltavaa joko kylmä-, kuuma tai höyrypesuria. Myös kiinteä pesuri tai robotti voi olla tarpeellinen suurenevissa yksiköissä. Tilojen ja laitteiden pesuissa voidaan säästää vettä käyttämällä lypsykoneputkiston pesuvesiä uudelleen tai kierrättämällä pesuvettä laitteen pesussa.

Kotieläintiloille suunnattu kyselytutkimus tehtiin maalis-huhtikuussa 2004. Siinä selvitettiin tilojen veden käyttöä, käyttöveden lähteitä, veden laatua, veden puutteesta johtuvien ongelmatilanteiden yleisyyttä sekä puutteen vaikutusta tilojen pesu- ja juomaveden käyttöön. Kyselyn kohderyhmäksi valittiin keskimääräistä suuremmat maidon-, naudanlihan-, broilerinlihan- sekä sianlihantuotantotilat. Kysely lähetettiin 430 tilalle. Keväällä 2005 suoritettiin täydentävä puhelinkysely 13 sikatilalle ja seitsemälle maitotilalle. Kyselyssä selvitettiin olivatko kesän ja syksyn 2004 sateet aiheuttaneet uusia kaivoveden käyttöön vaikuttavia laatuongelmia. Kesällä 2005 suoritettiin MTT Vakolassa pesukokeita painepesurilla. Pesukokeilla selvitettiin painepesurin veden, polttoaineen ja energian kulutusta.

Kyselytutkimukseen vastasi 92 maatilaa, vastausprosentti oli 21. Maatiloista 35 \% käytti toimintoihinsa vain oman kaivon vettä. Monella tilalla oli oman kaivon lisäksi kunnallinen vesi varavesilähteenä. Suurimmalla osalla tiloista ei ollut ollut vedestä pulaa, vaikka käyttöveden lähteenä oli vain tilan oma kaivo. Kuiva ajanjakso oli havaittu kaivoissa veden pinnan huomattavana laskuna sekä kaivoveden loppumisena. Kyselytutkimus antoi kuvan vesipulan laajuudesta ja maatilojen selviytymistavoista kuivuusongelmissa. Veden laatututkimus oli tehty 13 rengaskaivosta, joista kahdeksassa veden laatu ei täyttänyt sosiaali- ja terveysministeriön (STM) asettamia laatuvaatimuksia jonkin laatuparametrin osalta. Kyselyyn vastanneiden tilojen 29 porakaivoista oli tutkittu 12. Kaikissa näissä kaivoissa oli jokin tekijä, jonka takia veden laatu ei täyttänyt STM:n laatuvaatimuksia. Puhelinkyselyyn osallistuneilla tiloilla runsaat sateet eivät olleet vaikuttaneet kaivoveden laatuun.

Pesukokeessa matalaa painetta (60 bar) käyttäen saavutettiin pesuveden korkein lämpötila. Korkeimmilla paineilla vedenkulutus oli suurin. Eläintilojen pesussa tärkeää on myös hygienia, jota tässä tutkimuksessa ei otettu huomioon. Vedenkulutuksessa säästäminen voi johtaa riittämättömään puhdistustulokseen.

Avainsanat: maatilat, vesi, veden laatu, kuivuus, veden käyttö, veden lähde, kaivo 


\title{
Animal farms and their water supply
}

Sanna Sorvala, Maarit Puumala ja Marja Lehto

MTT Agrifood Research Finland, Animal Production Research, Vakolantie 55, FI-03400 Vihti, Finland, maarit.puumala@mtt.fi,marja.lehto@mtt.fi

\begin{abstract}
The objective of this project was to find out where animal farms take their water from, and what the quality of their water is. It was also studied how dry spells have affected the farm activities, what measures have been taken on the farms to save water, and what measures have been taken to be prepared for dry spells in the future. Problems caused by exceptionally rainy spells were also surveyed.

The water sources of agriculture, the use of drinking water for the animals, and the use of washing water on farms was surveyed in a review of the literature. The quality of well water is influenced by earth and bedrock composition, and by risk factors near the well. Many elements in the bedrock, as iron, fluorine, and arsenic, can dissolve into the ground water and thereby get into well water. Also cultivated fields, roads, animal barns, and waste water tanks near the well may affect the water quality. On farms, most of the water is consumed as drinking water for the animals.
\end{abstract}

For washing the animal sheds, portable washers working with hot water, cold water, or steam are used. On expanding farms, stationary washers or washing robots may also be necessary. Water can be saved by reusing water, for example by recycling the washing water for milking plants.

A questionnaire was sent to animal farms in March-April 2004. Their use of water, water sources, water quality, and the frequency of problematic situations due to shortage of water and how these situations affect the use of washing and drinking water was surveyed. The questionnaire was sent to 430 farms of bigger size than the average, which produce milk, beef, broiler, or pork. In spring 2005, a complementary telephone interview was done with 13 pork farms and seven dairy farms. It was surveyed if the exceptionally abundant rains in 2004 had caused new quality problems with well water. In summer 2005, washing trials with a high-pressure washer were conducted at MTT Agricultural Engineering Research. The consumption of water, fuel and energy in high-pressure washing was studied.

The questionnaire was answered by 92 farms, which was 21\%. 35\% of the farms only used their own well water. Many farms had municipal water as backup to their own well. Most of the farms had no shortage of water although their only water source was their own well. Dry spells had been noticed as considerable lower water level in their well and run out of well water. The questionnaire gave a picture of how common shortage of water is, and how farms overcome problems caused by drought. The farms had analysed the water quality of 13 dug wells, and eight of those did not fulfil all the requirements set by the ministry of social affairs and health. There were 29 drilled wells on the farms which answered the questionnaire, and 12 of those had been analysed. None of these 12 fulfilled all the requirements set by the ministry. None of the farms interviewed on the telephone had noticed impaired well water quality due to the abundant rains.

In the high-pressure washing trials, the highest temperature was reached with low pressure (60 bar). With the highest pressures the water consumption was highest. When washing animal sheds, however, hygiene is also important, and this study did not go into hygiene aspects. Saving on water consumption may lead to insufficient washing result.

Keywords: animal farms, water quality, drought, water use, water source, well 


\section{Alkusanat}

Suomen vesivarat ovat runsaat. Pintavettä riittäisi käytettäväksi jokaiselle suomalaiselle noin $60 \mathrm{~m}^{3}$ vuorokaudessa. Runsaimmat pohjavesilähteet sijaitsevat sora- ja hiekkamailla. Teollisuus ja maatalous käyttävät merkittävästi sekä pohja- että pintavettä. Veden kulutus on pienentynyt viime vuosikymmeninä kotitalouksissa ja teollisuudessa vettä säästävän teknologian käyttöönoton, taloudellisen ohjauksen, valistuksen ja vesijohtojen saneerausten ansioista. Veden kokonaiskulutukseksi Suomessa arvioidaan 1 milj. $\mathrm{m}^{3}$ vuorokaudessa, pohjavettä tästä on 0,6 milj. $\mathrm{m}^{3}$.

Suomessa ei ole ollut ongelmia veden riittävyydessä, kuten joissakin muissa Euroopan maissa. Tuotantoyksiköiden kasvaessa niissä kulutettavan veden määrä kasvaa oleellisesti, esim. lypsykarjatiloilla automaattilypsyyn siirtyminen lisää veden kulutusta. Jotta veden riittävyys ei aiheuta tuotantokatkoksia ja tulonmenetyksiä, on tuotannon laajennusta suunniteltaessa selvitettävä myös vedentarpeen kasvu. Tällä hetkellä ei ole olemassa selkeää käsitystä siitä, minkä verran missäkin tuotantomuodossa ja -kokoluokassa vettä kulutetaan.

Puhtaan veden käyttömäärään voidaan vaikuttaa valitsemalla kuhunkin kohteeseen oikeanlaiset, vettä säästävät vesikalusteet. Usein veden säästö perustuu oikean käyttöpaineen valintaan, mikä on otettava huomioon jo putkistoja ja liitoksia suunniteltaessa. Puhtaan veden kulutukseen voidaan vaikuttaa myös vettä kierrättämällä. Tällöin tulee olla riittävästi tietoa ensimmäisen käyttökohteen aiheuttamasta kuormituksesta ja toisaalta toissijaisen käyttökohteen laatuvaatimuksista. Veden kierrättämisen etuna on myös syntyvän jätevesimäärän ja niiden varastointiin tarvittavan tilan, useissa tapauksissa lietesäiliötilavuuden, pieneneminen.

Vuosina 2002 ja 2003 vallinnut poikkeuksellinen kuivuus on antanut aihetta miettiä käyttöveden riittävyyteen ja laatuun liittyviä kysymyksiä. Useilla maatiloilla, joilla käyttöveden lähteenä on vain oma kaivo, on ollut ongelmia veden riittävyydessä. Kaivot ovat kuivunet ja viljelijät ovat joutuneet säännöstelemään vedenkäyttöä. Veden käytön rajoittaminen on usein vaikeaa, sillä vettä tarvitaan tilalla moniin välttämättömiin toimintoihin, kuten eläinten juomavedeksi ja puhtaina pidettävien tilojen pesuun.

Tutkijat haluavat kiittää Marjatta ja Eino Kollin säätiötä, Maatalouskoneiden tutkimussäätiötä sekä Maa- ja vesitekniikan tukisäätiötä hankkeen rahoituksesta. Lisäksi haluamme kiittää niitä lukuisia kotieläintiloja, jotka kyselyymme vastaamalla mahdollistivat hankkeemme.

Vihdissä maaliskuussa 2006

Maarit Puumala

hankkeen vastuullinen johtaja 


\section{Sisällysluettelo}

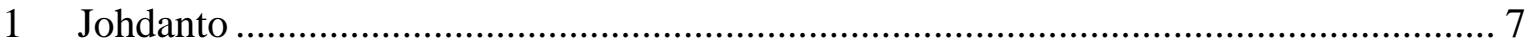

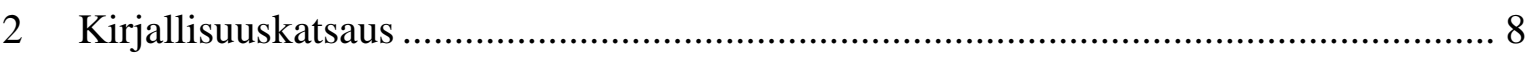

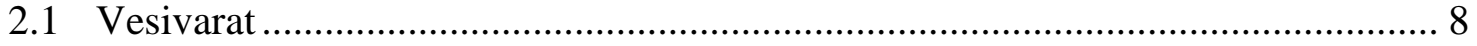

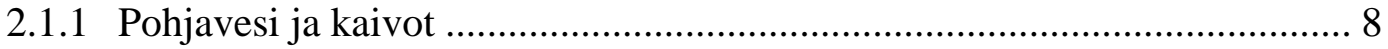

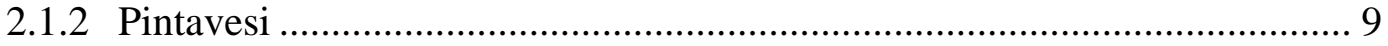

2.2 Käyttöveden laatu ja siihen vaikuttavat tekijät .................................................... 9

2.2.1 Kallio- ja maaperästä johtuvat tekijät........................................................ 10

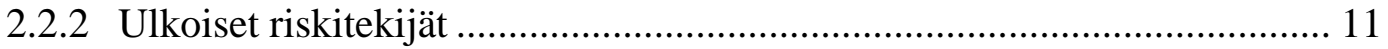

2.3 Veden laatuun vaikuttavien haittatekijöiden poisto............................................. 12

2.4 Veden käyttö ja laatuvaatimukset maatilalla ..................................................... 13

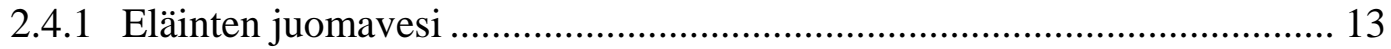

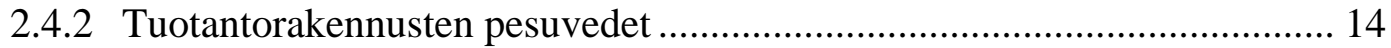

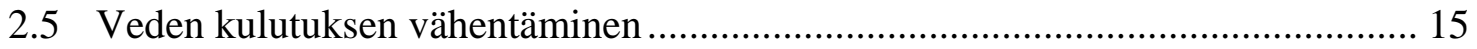

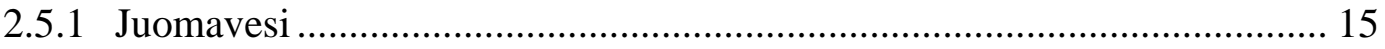

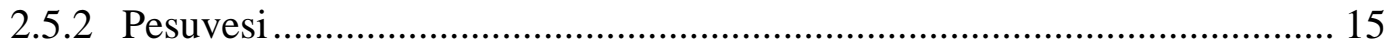

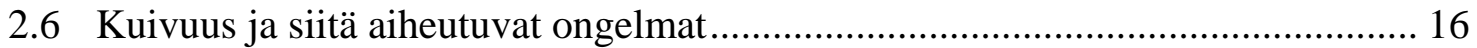

2.6.1 Keinoja kuivuuden aiheuttamien ongelmien ratkaisuun .......................... 16

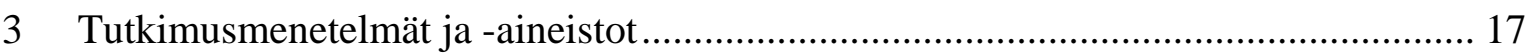

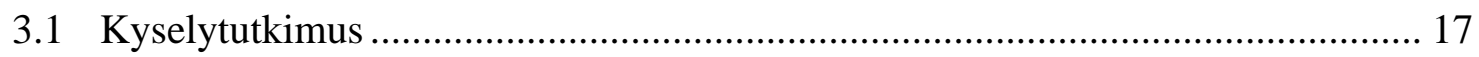

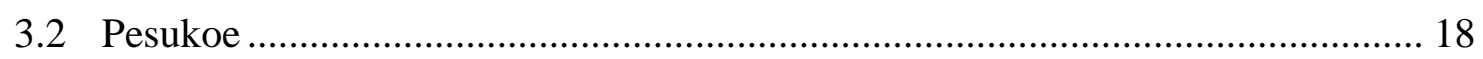

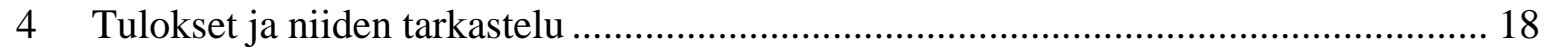

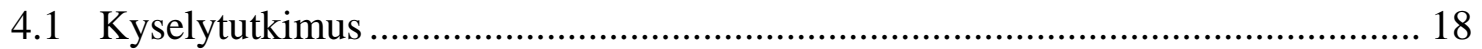

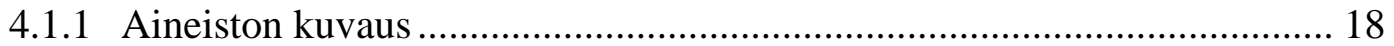

4.1.2 Käyttöveden lähde.............................................................................. 21

4.1.3 Juoma- ja pesuveden kulutus..................................................................... 22

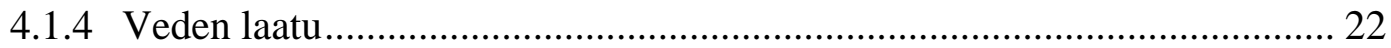

4.1.5 Veden riittävyys ja käytön tehostaminen ............................................... 24

4.1.6 Puhelinkyselyn tulokset............................................................................ 24

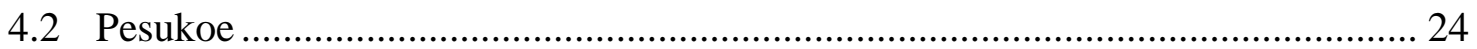

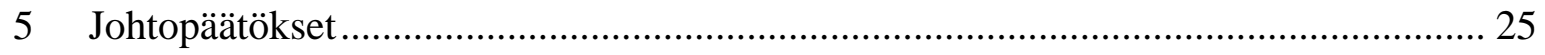

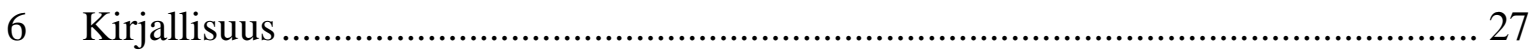

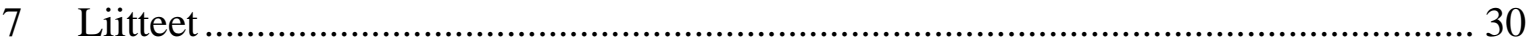




\section{Johdanto}

Vesi on tärkeä tekijä sekä kansallisena että globaalina kysymyksenä. Vedellä on monipuolinen merkitys mm. talousvetenä, ravinnontuotannossa, virkistyskäytössä ja yleisessä hyvinvoinnissa. Suomen vesivarat ovat huomattavat, mutta vuosina 2002 ja 2003 vallinnut poikkeuksellinen kuivuus on herättänyt käyttöveden riittävyyteen ja laatuun liittyviä kysymyksiä. Lähes 10000 kotitalouden ja yli tuhannen maatilan arvioidaan kärsineen tuona aikana vesipulasta, erityisesti Etelä- ja Keski-Suomessa. Kuivuus on lisännyt huomattavasti halukkuutta liittyä vesihuoltolaitosten verkostoihin ja uusia vesiosuuskuntia on perustettu tai niiden perustaminen on vireillä (Kotkasaari 2003). Haja-asutusalueella talousvedessä on usein puutteita ilman poikkeuksellista kuivuuttakin (Piirainen 2004).

Haja-asutusalueella vesi saadaan usein lähteistä, betonirengaskaivoista tai kallioporakaivoista. Kaivovesissä on usein laatuongelmia. Mahdollisia kaivoveden laatuun vaikuttavia riskitekijöitä ovat kaivojen läheisyydessä sijaitsevat jätevesisäiliöt, lantavarastot, eläinsuojat ja pellot. Yleisimpiä laatuun vaikuttavia kemiallisia tekijöitä ovat veden nitraatti-, mangaani-, kloridi-, magnesium-, rauta- ja kalsiumpitoisuudet sekä pH. Myös mikrobiologiset tekijät vaikuttavat veden laatuun (Korkka-Niemi 2001).

Vettä käytetään maatiloilla mm. eläinten juomavetenä, tuotantotilojen ja välineiden pesuvetenä sekä kastelu- ja talousvetenä. Eläinten juomaveden tarve riippuu mm. veden ja ilman lämpötilasta sekä ravinnon vesipitoisuudesta. Eläimille jatkuva veden saanti on tärkeää (Irwin 1986). Eläintilojen pesuveden käyttö riippuu pesumenetelmästä ja tuotantosuunnasta (Hörnig \& Schreping 1995). Veden säästöä ei ole yleensä huomioitu teknisiä ratkaisuja valittaessa, koska veden hankinta ei ole ollut oleellinen kustannuserä. Yksikkökoon kasvaessa ja kunnallisen vesijohtoverkoston laajentuessa myös vedenhankinnan kustannukset alkavat nousta merkittäviksi.

Vuosina 2002 ja 2003 Suomessa oli poikkeuksellisen kuivaa. Varsinkin Etelä- ja KeskiSuomessa satoi vuosien 1971-2000 keskiarvoa vähemmän syksyllä 2002 ja keväällä 2003 (Ilmatieteenlaitos 2005). Kesä ja syksy 2002 olivat myös vuosien 1971-2000 keskiarvoa lämpimämpiä. Loppukesällä 2002 sekä järvistä että maaperästä haihtui runsaasti vettä. Yleensä syyssateet täydentävät pohjavesivarastoja, mutta syksyllä 2002 ei tullut merkittäviä sateita. Talvi tuli vuonna 2002 aikaisin ja loppuvuoden sää oli hyvin kylmä. Myös vuoden 2003 tammikuu oli keskiarvoa kylmempi. Syksyllä 2002 ja alkuvuodesta 2003 pohjaveden pinta olikin suuressa osassa Suomea ennätyksellisen alhaalla (Suomen ympäristökeskus 2004a). Vuoden 2004 alkupuoliskolla edellisten vuosien kuivuus vaikutti pohjavesitilanteeseen voimakkaasti. Vuoden kokonaissademäärä oli kuitenkin koko maassa keskiarvoa suurempi ja loppuvuodesta pinta- ja pohjavesivarannot kasvoivat merkittävästi (Suomen ympäristökeskus 2005a).

Kuivat kaudet vaikuttavat veden saatavuuteen laskemalla pohjavesien ja järvien pintojen korkeutta sekä vähentämällä maan kosteutta. Eniten kuivuudesta kärsivät haja-asutusalueella olevat pohjavesikaivojen käyttäjät (Piirainen 2004). Monet maatilat saattavat kärsiä kuivuudesta, ellei niillä ole vaihtoehtoista vesilähdettä käytettävissään (Gabriel \& Kreutzwiser 1993). Suuri osa maatiloista joutuu vesipulan aikana säännöstelemään veden käyttöä, esim. vähentämällä eläintilojen pesua. Vettä tarvitaan välttämättömiin toimintoihin, kuten eläinten juomavedeksi ja puhtaana pidettävien tilojen pesuun, joten säännöstely voi olla vaikeaa. Huolimatta veden säästötoimenpiteistä, poikkeuksellisen kuivina kausina osalle maatiloista joudutaan vettä kuljettamaan muualta. 
Tutkimuksessa selvitettiin kirjallisuuden perusteella käyttöveden lähteet, laatu sekä laatuhaittojen poistaminen. Lisäksi selvitettiin veden tarvetta eläintilojen juoma- ja pesuvetenä. Suurille kotieläintiloille kohdistuva kyselytutkimus kartoitti maatilojen käyttöveden lähteitä sekä pesu- ja juomavesikäyttöä. Lisäksi selvitettiin, onko kuivuudesta aiheutunut ongelmia veden riittävyydessä tai ovatko runsaat sateet vaikuttaneet kaivoveden laatuun. MTT maatalousteknologian tutkimuksessa tehtiin painepesurilla pesukokeita, joissa selvitettiin pesurin veden ja energian kulutusta.

\section{Kirjallisuuskatsaus}

\subsection{Vesivarat}

\subsubsection{Pohjavesi ja kaivot}

Pohjavesi on maaperän huokosissa kulkevaa maaperään imeytynyttä sade- ja sulamisvettä. Maaperän laatu on tärkeä tekijä pohjaveden muodostumisessa (Lybeck ym. 2004). Eniten pohjavettä muodostuu harjuissa sekä sora- ja hiekka-alueilla. Savimailla pohjavettä muodostuu vähemmän (Suomen ympäristökeskus 2005a). Maakerrosten läpi suodattuessaan vesi puhdistuu metallien ja muiden haitallisten aineiden kiinnittyessä maan humuskerrokseen ja mineraalihiukkasiin. Pohjaveden pinta vaihtelee eri vuodenaikoina. Kevättalvella pohjaveden pinta on matalimmillaan, koska maan jäätymisen vuoksi pohjavettä ei muodostu. Pinta nousee keväällä sulamis- ja sadevesien imeytyessä maaperään. Kesällä kasvit käyttävät maan kosteuden hyväkseen, jolloin sadevesi ei ehdi imeytyä maaperään, ja pohjaveden pinta laskee. Syksyllä sateet täydentävät pohjavesivaroja (Lybeck ym. 2004).

Kaivoveden pinta on yleensä samalla tasolla kuin pohjavesi. Runsaan vedenoton yhteydessä kaivon vedenpinta laskee, mutta pyrkii palautumaan ennalleen (Lahermo ym. 1999). Määrällisiä muutoksia pohjaveteen voivat aiheuttaa kuivuus, rakentaminen, lähivesistöjen pinnan korkeuden muutokset, ojitukset sekä liiallinen vedenotto (Lybeck ym. 2004).

Suomessa haja-asutusalueen yksityiskaivoista pääosa on rengaskaivoja, joiden syvyys on kolmesta metristä viiteen metriin (Korkka-Niemi 2001). Kaivon sijoituksessa on otettava huomioon sekä vuodenaikojen että kuivien kausien aiheuttama vedenpinnan vaihtelu (Varsinais-Suomen Agenda 21 2004). Kaivon oikea sijoitus on alarinteessä siten, että sen pohja on talven ja loppukesän alimman pohjaveden tason alapuolella (Suomen ympäristökeskus 2005b). Hiekka- ja soramaihin kaivetuista kaivoista voidaan saada useita kymmeniä kuutiometrejä vettä vuorokaudessa, kun taas moreenimaahan kaivetuista kaivoista saadaan muutamia kuutiometrejä. Veden laatuun vaikuttavat kaivon renkaiden ja kansirakenteiden kunto ja tiiviys sekä kaivon pohjalla olevan suodatinkerroksen puhtaus (Lahermo ym. 2002).

Kallioporakaivo on kallioon porattu 20-150 m syvä reikä, josta pumpataan kalliovettä (Lybeck ym. 2004). Porakaivojen antoisuus on yleensä 500-2 $000 \mathrm{l}$ tunnissa, eli 10-50 kuutiota vuorokaudessa (Lahermo ym. 2002). Antoisuudeltaan parhaat kallioporakaivot sijaitsevat kallioperän ruhjevyöhykkeessä. Kallioporakaivon rakentamisen ongelmana on, ettei etukäteen tiedetä porattavan kaivon antoisuutta tai veden laatua. Kaivon antoisuuden tutkimisessa voidaan käyttää apuna erilaisia tutkimusmenetelmiä, kuten kaukokartoitusta, ruhjetulkintoja ja seismistä luotausta. Näistä menetelmistä ei mikään kuitenkaan anna täyttä varmuutta veden laadusta tai kaivon antoisuudesta (Varsinais-Suomen Agenda 21 2004). 
Siiviläputkikaivo rakennetaan sora- ja hiekkamaaperään, kun halutaan hyödyntää laajoja ja syviä pohjavesivarastoja. Lähdekaivo hyödyntää pohjaveden luontaista ylivuotoa. Lähdekaivo voi olla esim. katoksella suojattu lähteensilmäke tai normaali rengaskaivo. Nykyisin lainsäädännöllä kielletään lähdekaivojen rakentaminen, jos lähteen säilyminen luonnontilaisena vaarantuu. Lähteestä saa ottaa vettä nykyisinkin tilapäisesti, jos käyttö ei aiheuta haittaa muille tai ympäristölupavirasto myöntää kiellosta poikkeuksen (Lybeck ym. 2004).

Tutkimusten mukaan kaivon syvyys vaikuttaa koliformien ja nitraattien esiintymiseen vedessä. Vesitilavuudeltaan pienet kaivot ovat alttiimpia likaantumiselle, koska ne ovat usein matalia (Goss et al. 1988) ja rakennettu vain pohjaveden pintaan asti (Hallberg \& Kross 1990). Vanhojen kaivojen rakenteet voivat olla myös huonokuntoisia, mikä saattaa vaikuttaa heikentävästi veden laatuun. Koliformisten bakteerien määrän on havaittu vähenevän, kun kaivon etäisyys eläinsuojasta kasvaa mutta kaivon etäisyydellä jätevesisäiliöstä ei ole havaittu olevan vaikutusta vedessä olevien bakteerien määrään (Goss et al. 1988).

\subsubsection{Pintavesi}

Pintavesi on hapen ja typen kyllästämää vettä, joka sisältää savea, humusta ja bakteereja. Pintavesien laatu vaihtelee vuodenaikojen mukaan riippuen sadannasta ja valumaveden mukana kulkeutuneen materiaalin määrästä. Suomen järvi- ja jokivedet ovat vähämineraalisia ja happamia, pH 6-7 (Kansanterveyslaitos 2002). Suomessa humuksen antama ruskea väri on luonteenomainen suurimmalle osalle vesistöistä. Muita väriä antavia aineita ovat rauta, levät sekä useat muut kiinteät ja liuenneet aineet.

Pintaveden laatuun juomavetenä voivat vaikuttaa myös sinileväkukinnat. Sinilevät ovat mm. pintavesissä eläviä sinibakteereita, jotka pystyvät yhteyttämään kasvien tavoin. Levien lisääntymiseen vaikuttavat vuodenaikojen lisäksi monet tekijät, mm. fosfori ja typpi. Erityisesti ylimääräinen fosfori vaikuttaa levien esiintymiseen sisävesissä ja rannikkoalueilla. Yksisoluiset levät voivat nousta veden pinnalle solunsisäisten kaasurakkuloiden tai öljypisaroiden avulla. Lopulta levämassa muodostaa veden pinnalle lauttoja. Leväkukinta on vapaasti vedessä elävien sinilevien runsasta esiintymistä veden pinnalla, mikä näkyy vihertävinä tai keltaisina palloina. Levistä on haittaa silloin, kun niitä on liikaa. Osa sinileväkukinnoista on myrkyllisiä. Sinilevä voidaan todeta esimerkiksi ottamalla tutkittavaa vettä lasiin, jossa sen annetaan seistä vähän aikaa. Jos levää nousee pintaan, kyseessä on todennäköisesti sinilevä. Järvivettä, jossa on sinilevää, ei saa käyttää juomavetenä. Järvivedessä voi olla myös muita terveydelle vaarallisia epäpuhtauksia. Eläimet eivät välttele leväpitoista vettä, joten niillä on ihmistä suurempi riski saada levämyrkytys (Rissanen ym. 1999).

\subsection{Käyttöveden laatu ja siihen vaikuttavat tekijät}

Kaivoveden laatu vaihtelee maaperätekijöistä johtuen eri puolilla Suomea sekä paikallisesti. Veden laatuun vaikuttavat tekijät voivat vaihdella paljonkin jopa vierekkäisten kaivojen välillä (Lahermo ym. 2002). Haitallisten aineiden korkeat pitoisuudet kaivovesissä voivat johtua kallio- tai maaperän rakenteesta ja koostumuksesta. Tavallisia lika-aineiden lähteitä ovat maatalouden, asutuksen, liikenteen ja teollisuuden päästöt, jotka pääsevät huonosti suojattuihin kaivoihin (Lahermo ym. 2002). Päästölähteinä voivat olla mm. jätevesisäiliöt, lantavarastot, eläinsuojat ja pellot. Riskitekijä voi vaikuttaa kaivoveden laatuun kaukaakin, joten yksiselitteisiä ohjeita kaivon etäisyydestä riskitekijöihin ei voida antaa. Yleisimpiä veden laatuun vaikuttavia kemiallisia tekijöitä ovat veden nitraatti-, mangaani-, kloridi-, magnesium-, rauta- ja kalsiumpitoisuudet sekä pH. Lisäksi vedessä voi olla mm. alumiinia, 
arseenia, radonia, sulfaatteja ja orgaanista materiaalia (Korkka-Niemi, 2001). Myös mikrobiologiset tekijät vaikuttavat veden laatuun. Sosiaali- ja terveysministeriön talousvesiasetuksen (401/2001) mukaiset laatuvaatimukset ja suositukset on esitetty taulukossa 1. (Lahermo ym. 2002).

Taulukko 1. Talousvedelle asetettavat laatuvaatimukset (STM 401/2001)

\begin{tabular}{|c|c|c|c|}
\hline Laatukriteeri & yksikkö & $\begin{array}{l}\text { Laatusuositus } \\
\text { (enimmäispitoisuus) }\end{array}$ & $\begin{array}{l}\text { Laatuvaatimus } \\
\text { (enimmäispitoisuus) }\end{array}$ \\
\hline Escherichia coli & pmy $/ 100 \mathrm{ml}$ & & 0 \\
\hline $\begin{array}{l}\text { Suolistoperäiset } \\
\text { enterokokit }\end{array}$ & $\mathrm{pmy} / 100 \mathrm{ml}$ & & 0 \\
\hline Koliformiset bakteerit & pmy/ $100 \mathrm{ml}$ & & 0 \\
\hline Nitraatti & $\mathrm{mg} / \mathrm{l}$ & & 50 \\
\hline Nitriitti & $\mathrm{mg} / \mathrm{l}$ & & 0,5 \\
\hline Fluoridi & $\mu \mathrm{g} / \mathrm{l}$ & & 1,5 \\
\hline rseeni & $\mu g / l$ & & 10 \\
\hline Ammonium & $\mathrm{mg} / \mathrm{l}$ & 0,50 & \\
\hline $\mathrm{pH}$ & & $6,5-9,5$ & \\
\hline Kloridi & $\mathrm{mg} / \mathrm{l}$ & 100 & \\
\hline Rauta & $\mu g / l$ & 200 & \\
\hline Radon & $\mathrm{Bq} / \mathrm{l}$ & 300 & \\
\hline $\mathrm{KMnO}_{4}$-luku & $\mathrm{mg} / \mathrm{l}$ & 20 & \\
\hline haju, maku & & $\begin{array}{l}\text { ei selvää vierasta } \\
\text { hajua tai makua }\end{array}$ & \\
\hline
\end{tabular}

\subsubsection{Kallio- ja maaperästä johtuvat tekijät}

Tärkeimmät pohjaveden laatua heikentävät maaperätekijät ovat korkeat rauta-, mangaanija fluoripitoisuudet. Lisäksi vedessä voi olla mm. kloridia, alumiinia, arseenia, radonia, sulfaattia ja orgaanisia aineita.

Luonnontilaisten pohjavesien kloridipitoisuus on keskimäärin 2,1 mg/l (Suomen ympäristökeskus 2004c). Tärkeimpiä kloridien luonnollisia lähteitä ovat savikerrosten alaiset kerrostumat ja kallioperä. Kloridipitoisuudet ovat korkeita rapakivialueilla ja meren läheisyydessä (Korkka-Niemi 2001). Kaivovedessä oleva suuri kloridipitoisuus saattaa johtua liian syvästä porakaivon reiästä. Vettä voidaan myös ottaa kaivosta liian suuria määriä muodostuvaan pohjaveteen verrattuna, jolloin kloridipitoinen vesi pääsee nousemaan porakaivoon. Jos kloridipitoinen vesi sekoittuu suolattoman veden kanssa, kloridipitoisuuden poistaminen kaivosta saattaa kestää hyvinkin pitkän ajan. Tällainen kaivo on käytännössä pilalla. Jo $25 \mathrm{mg} / \mathrm{l}$ kloridipitoisuus voi aiheuttaa putkistojen ja muiden vesikalusteiden syöpymistä, mistä aiheutuu taloudellisia kustannuksia (Lahermo ym. 2002).

Radonin isotooppi ${ }^{222} \mathrm{Rn}$ kuuluu yleisimmän luonnossa olevan uraani-isotoopin hajoamissarjaan. Kaasumaisena radon sekä liikkuu veteen liuenneena että pyrkii karkaaman maaperästä ilmaan. Radon kulkeutuu maaperässä helpommin karkeilla hiekka- ja soramailla kuin tiiviillä savimailla. Sitä esiintyy erityisesti porakaivovedessä, jossa sen pitoisuus on kymmenkertainen verrattuna rengaskaivoveteen. Rengaskaivoista radon vapautuu helposti ilmaan, kun taas porakaivoista se vapautuu ilmaan vasta vettä käytettäessä. Kallioperän ruhjeesta purkautuvan radonin alkulähde voi olla satojen metrien syvyydessä. Radonin ohella porakaivovesissä voi esiintyä myös huomattavia määriä uraania (Säteilyturvakeskus 2003). 
Arseeni on radonin ohella pahimpia yksittäisen kaivon veden laatuongelmien aiheuttaja. Arseenia on kaikkialla luonnossa pieninä pitoisuuksina. Korkeat arseenipitoisuudet pohjavedessä ovat peräisin kallio- ja maaperässä luontaisesti olevasta arseenista. (Lahermo ym. 2002). Arseenipitoista pohjavettä voidaan käyttää talousvetenä, mutta ei ruuan valmistukseen eikä juomavetenä. (Suomen ympäristökeskus 2002).

Fluori on yleinen alkuaine geologisissa esiintymissä. Vedessä fluori on liuenneena fluoridiionina ja se pystyy myös muodostamaan happamissa vesissä yhdisteitä alumiinin kanssa. Kaakkois- ja Lounais-Suomessa on alueita, joilla pohjavesien fluoridipitoisuudet ovat liian korkeita. Fluoripitoisuudet ovat näillä alueilla yleensä 1,5-2,5 mg F/l ja joissakin yksittäistapauksissa jopa 3,5-4,5 mg F/l. Fluoripitoisuudet ovat korkeimpia happamassa kallioperässä, vaikka selvää yhteyttä fluoridipitoisuuden ja kallioperän koostumuksen välillä ei ole havaittu (Sæther et al. 1995). Suomessa on myös alueita, joissa fluoridipitoisuus on erittäin alhainen (Korkka-Niemi 2001).

Kallioperässä oleva rauta liukenee pelkistävissä olosuhteissa veteen. Runsas orgaaninen aines ja pelkistävät olosuhteet edistävät raudan liukenemista ja kulkeutumista veden mukana. Rautaa voi kulkeutua myös huonosti suojattuun kaivoon humuspitoisen pintavalunnan mukana. Rauta aiheuttaa veteen teknisiä, esteettisiä ja makuhaittoja. Rauta on myös eräs suurimmista pohjaveden laatuongelmien aiheuttajista Suomessa (Lahermo ym. 2002, Korkka-Niemi 2001).

\subsubsection{Ulkoiset riskitekijät}

Yhdyskuntajätevesistä, karjatalouden tuottamista jätteistä ja lannoitteista huuhtoutuu sekä maahan että pohjaveteen monia orgaanisia ja epäorgaanisia lika-aineita, joiden luontaiset pitoisuudet pohjavedessä ovat hyvin pieniä. Tyypillisiä likaantumisen seurauksena kaivoon joutuneita aineita ovat typpiyhdisteet, erityisesti niiden lopulliset hapetustuotteet, nitraatit. Nitraattia on kaivovesissä kaikkialla Suomessa, mutta maankäytön sekä topografisten ja hydrologisten olosuhteiden vaihtelevuudesta johtuen kaivojen likaantuminen on paikallista ja nitraattipitoisuuksien vaihtelut voivat olla suuria saman alueen kaivoissa (Lahermo ym. 2002). Kaivoveden nitraattipitoisuus osoittaa herkimmin asutuksesta tai maataloudesta peräisin olevan kuormituksen. Kotieläinten lantaa levitettäessä on kaivojen ympärille jätettävä maaston korkeussuhteista, kaivon rakenteesta ja maalajista riippuen, 30-100 m levyinen lannoittamaton vyöhyke (VN 931/2000). Suojavyöhykkeet eivät aina kuitenkaan auta, koska nitraatit voivat kulkeutua pitkänkin matkan päästä kaivoveteen (Lapinlampi ym. 2001).

Kallioperän koostumus vaikuttaa pohjaveden laatuun (Korkka-Niemi 2001). Fluoridipitoisuudet ovat korkeimmat happamassa kallioperässä, mutta selvää yhteyttä ei ole havaittu fluoridipitoisuuden ja kallioperän koostumuksen välillä. Suomessa fluoridipitoisuudet ovat ongelma rajoitetulla alueella Etelä-Suomessa. Korkka-Niemen (2001) tutkimuksen mukaan 7 \% kaivovesistä ylitti sallitun fluoridipitoisuuden.

Nitraattien lisäksi myös kaivovedessä satunnaisesti esiintyvä korkea fosforipitoisuus on merkki kaivoon päässeistä lannoitteista tai muuten likaantuneista valumavesistä. Kaivovedessä olevat arseeni- ja kadmiumpitoisuudet voivat olla peräisin lannoitteista, jos peltomaan pintakerrokseen on rikastunut kadmiumia. Kuitenkaan viime vuosina peltomaan kadmiumpitoisuudet eivät ole kohonneet, koska Suomessa ei ole käytetty ulkomaisia fosforilannoitteita. Kadmium voi olla peräisin myös rehuista, joita tulee peltoon karjanlannan mukana (Lahermo ym. 2002). 
Jätevedet ovat selkeä riski kaivoveden laadulle. Kaivovedessä esiintyvät nitraatit tai ammoniumtyppi voivat olla peräisin jätevesistä. Myös taudinaiheuttajamikrobit voivat kulkeutua jätevesijärjestelmistä sadeveden mukana kaivoveteen (Lapinlampi ym. 2001). Parhaimpana ulosteperäisen saastumisen osoittajana pidetään Escherichia coli bakteeria, jota on havaittu esiintyvän kaivoissa, jotka sijaitsevat lähellä jäteveden imeytyspaikkaa tai karjasuojaa (Korkka-Niemi 2001).

Tiestö on usein rakennettu kantaville ja vähän routiville, mutta samalla hyvin vettä johtaville maaperäalueille, jotka ovat tärkeitä vedenhankinnan kannalta. Näillä hiekka- ja soraalueilla suola kulkeutuu helposti maantieltä pohjaveteen, jolloin veden kloridipitoisuudet nousevat luonnontilaisia pitoisuuksia korkeammiksi. Pohjaveden kloridipitoisuudet ovatkin nousseet monella alueella, missä teitä on suolattu (Korkka-Niemi 2002). Pohjavesimuodostumien puhdistuminen hydrologisen kierron kautta kestää vuosia (Suomen ympäristökeskus 2004a). Esimerkiksi pohjavesien kloridipitoisuudet eivät ole vähentyneet Salpausselän alueella, vaikka teiden suolausta on vähennetty ja luiskasuojauksia rakennettu 1990-luvulta alkaen (Suomen ympäristökeskus 2004b, Tiehallinto 2004, Hellstén ym. 2002 ).

\subsection{Veden laatuun vaikuttavien haittatekijöiden poisto}

Radonin poistoon voidaan käyttää ilmastusta tai aktiivihiilisuodatusta. Ilmastuksella pystytään poistamaan suuretkin radonpitoisuudet riittävän alhaiselle tasolle. Radonpitoista vettä ilmastettaessa vesi ja suuri määrä ilmaa sekoitetaan tasaisesti, jolloin radon siirtyy vedestä ilmaan. Tämän jälkeen radonpitoinen ilma johdetaan putkea pitkin ulkoilmaan. Aktiivihiilisuodatuksessa vesi suodatetaan aktiivihiilen läpi ja radon pidättyy hiileen. Teknisenä menetelmänä aktiivihiilisuodatus toimii hyvin, mutta sen haittapuolena on radioaktiivisen aineen kertyminen suodattimeen, josta puolestaan kulkeutuu ympäristöön gammasäteilyä. Pienessä mittakaavassa radonpitoisuutta voidaan pienentää myös vettä keittämällä.

Arseenin ja fluorin tehokkaaseen poistoon vedestä voidaan käyttää käänteisosmoosilaitteistoa tai aktivoitua alumiinioksidisuodatusta. Käänteisosmoosissa puhdas vesi läpäisee kalvon fluoridin, arseenin ja muiden suolojen jäädessä kalvolle. Menetelmä perustuu kalvoerotustekniikkaan, jossa korkeapainepumpulla tuotetaan riittävän korkea painetaso, jotta puhdas vesi pystyy läpäisemään kalvon. Käänteisosmoosilaitteistossa olennaista on oikea kalvotyyppi. Rengaskaivoveden arseenipitoisuutta voidaan joissain tapauksissa vähentää myös kaivon kunnostamisella (Suomen ympäristökeskus 2004c).

Raudan poistoon juomavedestä on useita menetelmiä. Pelkistyneen raudan poistamiseen voidaan soveltaa ioninvaihtoa, jossa käytetään kationista massaa. Kun rauta hapettuu, se saostuu ioninvaihtomassaan ja tukkii sen. Rautaa voidaan poistaa vedestä myös hapettamalla. Hapettamiseen voidaan käyttää kemikaaleja, kuten klooria, kaliumpermanganaattia tai vetyperoksidia, tai se voidaan suorittaa ilmastamalla. Kotitalouksissa on yleisesti käytetty raudan hapettamiseen katalysoivia massoja. Massa tehostaa hapettumista, joten suodatin voi olla kohtuullisen pieni mutta mitoituksessa on kuitenkin otettava huomioon pelkistyneen raudan massaa tukkivat ominaisuudet. Mangaanin poisto juomavedestä on hankalampaa kuin raudan, mutta katalysoivat massat soveltuvat myös mangaanin poistoon (Suomen ympäristökeskus 2004d).

Kaivo on kunnostettava ja puhdistettava huolellisesti, jos sinne on päässyt ulosteperäisiä, koliformisia, bakteereita. Ensin on kuitenkin selvitettävä kaivon saastumisen aiheuttaja. Kaivon puhdistaminen aloitetaan veden poispumppauksella. Tyhjennyksen jälkeen kaivo pestään rengas renkaalta ylhäältä alaspäin. Samalla korjataan mahdolliset halkeamat ja tiivistetään renkaiden välit. Kaivon pohjalle muodostunut liete poistetaan ja tilalle lisätään 
soraa. Ulosteperäisten bakteerien saastuttama kaivo pitää desinfioida (Varsinais-Suomen Agenda 21 2004). Desinfiointi voidaan suorittaa esim. vetyperoksidilla, joka sekoitetaan veteen ja seos valutetaan laitoja pitkin kaivoon. Putkistojen desinfioimiseksi, desinfiointiaineen annetaan seistä putkistossa, minkä jälkeen se huuhdotaan. Vesi on käyttökelpoista, kun desinfiointiaineen makua ja hajua ei tunnu (Lapinlampi ym. 2001).

\subsection{Veden käyttö ja laatuvaatimukset maatilalla}

\subsubsection{Eläinten juomavesi}

Eläimet tarvitsevat vettä moniin elimistön tehtäviin, kuten kudosten ylläpitoon, kasvuun, maidontuotantoon ja lisääntymiseen. Vesi on tärkeä tekijä myös lämmön säätelyssä, vierasaineiden erityksessä ja suolatasapainon säätelyssä. Vettä tarvitaan eläinten kylläisyyden tunteen saavuttamiseen sekä käyttäytymisviettien tyydyttämiseen. Veden tarpeeseen vaikuttavat ympäristön ja veden lämpötila sekä rehun koostumus ja määrä (Zimmerman et al. 2002). Taulukossa 2 on esitetty eläinlajien tarvitsemia juomavesimääriä. Eläimille tulisi olla vettä jatkuvasti tarjolla.

Taulukko 2. Eläinten tarvitsemia juomavesimääriä

\begin{tabular}{l|c|l}
\hline Eläin & Veden tarve l/eläin/vrk & Viite \\
\hline Lypsylehmä & $100-120$ & Virta (2002) \\
Ummessa oleva lehmä & $10-20$ & \\
\hline Lihanauta & $22-60$ & \\
\hline Porsiva emakko & $22-27$ & Virta (2002) \\
\hline Tiineenä oleva emakko & $12-17$ & \\
\hline Karju & 10 & \\
\hline Porsas $10-15 \mathrm{~kg}$ & $1,0-1,5$ & \\
\hline Porsas $15-25 \mathrm{~kg}$ & $1,5-2,5$ & \\
\hline Sika $40-60 \mathrm{~kg}$ & $4,0-5,5$ & Agronet (2005) \\
\hline Sika $90-120 \mathrm{~kg}$ & 7,0 & \\
\hline Broileri $7-14$ vrk & $0,06-0,12$ & \\
\hline Broileri $21-28$ vrk & $0,17-0,2$ & \\
\hline Broileri $35-70$ vrk & $0,2-0,35$ & \\
\hline
\end{tabular}

Eläinten juomaveden tulisi täyttää talousveden laatukriteerit. Jos juomaveden laatu ei ole hyvä, eläin voi lopettaa juomisen tai sairastua. Tuottajan tulisi tutkituttaa eläinten juomavedeksi käyttämänsä kaivovesi tai selvittää kunnan tai osuuskunnan veden laatu säännöllisin väliajoin. Eläinten juomavesi ei saa sisältää haitallisia mikrobeja, kemikaaleja, ulosteita tai muuta likaa. Vedessä ei saa olla vierasta hajua. Veden tulisi olla kirkasta ja väritöntä, eikä se saisi aiheuttaa merkittävää syöpymistä tai saostumista putkistoissa (Virta 2002).

Karjaan vaikuttaa herkästi sekä veden kemiallisen että mikrobiologisen laadun heikkeneminen. Likaantunut vesi voi aiheuttaa muutoksia veden juontimäärään, mikä vaikuttaa sekä eläinten terveyteen että kasvuun ja tuotostasoon. Tutkimusten mukaan eläimet voivat yhdistää pahan hajuisen veden ja sairauden. Kun eläimet ovat luoneet tämän mielleyhtymän, ne voivat lopettaa pahan hajuisen veden juomisen (Zimmerman et al. 2002). 
Juomaveden lämmittämisestä naudoille on ristiriitaisia tuloksia, jotka eivät kannusta veden lämmittämiseen. Veden lämmityksestä kylmissä olosuhteissa ei ole todettu olevan hyötyä. Suomessa veden lämpötilaksi on yleensä suositeltu $17^{\circ} \mathrm{C}$, jota on pidetty riittävän kylmänä estämään mikrobien kasvu, mutta tarpeeksi lämpimänä, jotta suuren vesimäärän juominen olisi mahdollista. Eläin juo lämmitettyä vettä enemmän, mutta päivittäinen tuotos tai kasvu ei merkittävästi nouse verrattuna kylmän veden juontiin (Virta 2002). Pakkasella on luonnollisesti varmistettava juomaveden pysyminen sulana

Laitumella lehmille saattaa olla vapaasti tarjolla pintavesiä (oja- tai järvivettä) tai juomavesi otetaan lähteestä. Laidunkauden alussa vesi saattaa olla moitteetonta, mutta sen laatu heikkenee helposti eläinten likaamana, jolloin lämpimällä ilmalla mikrobikasvusto lisääntyy pintavedessä (Virta 2002). Seisova, luonnollisesti ravinteikas vesi voi sisältää suuren määrän sinilevää, joka voi olla myrkyllistä karjalle ja johtaa eläinten kuolemaan. Lehmät voivat myös juoda maasta, juoma-astian vierestä likaantunutta vettä, koska se on niille fysiologisesti luonnollisempaa, jolloin veteen voi olla liuenneena erilaisia suoloja (Gadberry 2000). Karjan pääsy tällaisten vesien ääreen olisi estettävä.

\subsubsection{Tuotantorakennusten pesuvedet}

Lypsykarjatiloilla vettä käytetään mm. utareiden, lypsykoneen, tilasäiliön, lypsyastioiden, vasikoiden juottoastioiden ja maitohuoneen lattioiden pesuun (Kallio \& Santala 2002). Lypsylaitteiston pesussa pesuautomaattia käyttävillä tiloilla vettä kuluu vuorokaudessa $400-1000 \mathrm{l}$ eli vuodessa $146-365 \mathrm{~m}^{3}$. Lypsyrobottia käytettäessä veden kulutus on robotista riippuen 450 -1 000 l/vrk (Petersson 2002).

Tutkimuksen (Kapuinen \& Karhunen 1990) mukaan parsinavetoiden pesussa muodostuu pesuvesiä keskimäärin 126 litraa päivässä eli $46 \mathrm{~m}^{3}$ vuodessa. Nautayksikköä kohti pesuvesiä kertyy noin 6 litraa päivässä ja vuodessa $2,2 \mathrm{~m}^{3}$. Pihatoissa pesuvesien määrä on kyseisen tutkimuksen mukaan keskimäärin $60 \mathrm{~m}^{3}$ vuodessa eli 160 litraa päivässä. Lihakarjankasvattamossa pesuvesiä kertyy 1,8 $\mathrm{m}^{3}$ vuodessa eli 5 litraa päivässä. Larssonin (2000) mukaan pesuveden kulutus sikatiloilla on noin $1,1 \mathrm{~m}^{3}$ karsinaa $\left(8 \mathrm{~m}^{2}\right)$ kohti, jos likaa on vaikea irrottaa. Lian irrotessa helpommin veden kulutus on pienempi.

Lypsykarja- ja sikatilojen pesuveden kulutus vaihtelee riippuen pestävän tilan koosta, käytettävästä tekniikasta sekä pesutavoista (Fulhage \& Hoehne 2005, Hörnig \& Schreping 1995, European Commission 2003). Hollantilaisen tutkimuksen mukaan vedenkulutuksen ero voi olla jopa kuusinkertainen samankokoisissa navetoissa (Helminen ym. 1998). Taulukossa 3 on esitetty lypsykarja- ja sikatiloille tyypillisiä pesuveden käyttömääriä.

Taulukko 3. Lypsykarja- ja sikatiloille tyypillisiä pesuveden käyttömääriä (Fulhage \& Hoehne 2005)

\begin{tabular}{llc}
\hline Tuotanto alue & yksikkö & Tyypillinen veden käyttö \\
\hline Maitohuone & I/lehmä/vrk & $30-45$ \\
Porsaskasvatus & I/sika/vrk & $0,2-3$ \\
Lihasikala & I/sika/vrk & 0,4 \\
\hline
\end{tabular}

Maidon lypsylaitteiston pesu on suoritettava hyvälaatuisella talousvedellä. Veden laadun on oltava sosiaali- ja terveysministeriön asetuksen 401/2001 vaatimusten mukaista (MMM 2002). Veden tulee olla kirkasta ja väritöntä, ilman vieraita hajuja ja makuja. Siinä ei saa olla haitallisia mikrobeja tai kemiallisia aineita, jotka voivat aiheuttaa terveyshaittoja veden käyttäjälle tai huonontaa maidon laatua. 
Siipikarjatiloilla tarvittavan pesuveden määrä riippuu lintulajista sekä tuotantotavasta. Broilereiden kasvatushalli pestään jokaisen broilerierän jälkeen. Jotta jätevesimäärät pysyisivät kohtuullisina, on broilerihallin pesemiseen käytettävä korkeapaine- tai höyrypesuria (Ympäristöministeriö 1998). Broilerihallin pesussa kuluu vettä lintua kohden 2-20 litraa (European Commission 2003).

\subsection{Veden kulutuksen vähentäminen}

Veden kulutusta voidaan vähentää monin eri tavoin. Kotieläintuotannossa säästötoimet kohdistuvat pääosin laitteiden ja tuotantotilojen pesuvesiin, mutta voivat koskea tietyin rajoituksin myös juomavettä.

\subsubsection{Juomavesi}

Veden kulutusta ja hukkaveden määrää voidaan vähentää asianmukaisilla laitteilla. Nautojen ja sikojen juomalaitteina kuulanipat säästävät vettä. Kuulanippojen vedenkulutuksesta on tehty tutkimus (Larsson 1997), jossa verrattiin kuulanippaa ja perinteistä tappinippaa. Tutkimuksessa verrattiin veden kulutusta ja haaskausta sekä nippamallien vaikutusta eläinten painonlisäykseen ja rehun kulutukseen. Keskimääräinen vedenkulutus eläintä kohden oli kuulanipalla 37 \% pienempi kuin tappinippaa käytettäessä. Vettä meni hukkaan kuulanipoilla $24 \%$ ja perinteisillä tappinipoilla $32 \%$ kokonaisvedenkulutuksesta. Veden virtausnopeus oli pienempi kuulanipoilla kuin tappinipoilla, mistä saattoi johtua haaskatun vesimäärän ero. Juomanipoilla ei havaittu olevan vaikutusta eläinten painonlisäykseen. Erityisesti tilat, joilla on vedestä pulaa, hyötyvät kuulanippojen käytöstä (Rath 2000).

\subsubsection{Pesuvesi}

Puhdasta vettä voidaan säästää veden kierrätyksellä. Lypsykoneputkiston pesuvesien kierrätyslaitteita on toimintaperiaatteeltaan kahdenlaisia, varastopesujärjestelmiä ja kierrätyspesujärjestelmiä. Varastopesujärjestelmässä samaa pesuvettä käytetään usealla peräkkäisellä pesukerralla ja edellisen pesun jälkihuuhteluvedet käytetään seuraavan pesukerran esihuuhteluvetenä. Kierrätyspesujärjestelmässä ensimmäisen pesukerran loppuhuuhteluvesi käytetään seuraavan kerran pesuvetenä ja tämä vielä kolmannen pesukerran alkuhuuhteluvetenä. Varastopesujärjestelmä vähentää veden kulutusta 60 \% ja kierrätyspesujärjestelmä 66 \% (Helminen ym. 1998).

Lypsykoneen ja tilasäiliön pesuautomaateista on mahdollista ottaa talteen huomattava määrä vettä, jota voidaan käyttää muuhun tarkoitukseen. Sillä, mistä pesuvaiheesta kierrätettävä vesi on peräisin, on vaikutusta uudelleen käytettävän veden määrään, laatuun sekä veden käyttömahdollisuuteen ja käyttökohteeseen. Uudelleen käyttöön soveltuvat erityisesti väli- ja loppuhuuhteluvedet. Kun lypsykoneen ja tilasäiliön pesuvedet käytetään uudelleen, puhtaan veden kulutus voi laskea jopa puoleen. Esimerkiksi n. 40 lehmän navetassa kierrätettävää vettä voi kertyä pelkästään väli- ja loppuhuuhteluvesistä n. 65-70 $\mathrm{m}^{3}$ vuodessa (Korkeamäki ym. 2003).

Jos veden käyttöä siivouksessa voidaan tehostaa, vähentää se myös käsiteltävän jäteveden määrää. Eläinsuojien pesussa tulisikin käyttää korkeapainepesureita (Hörnig \& Schreping 1995).

Navetoiden ja sikaloiden pesuun soveltuu kuumapesuyksikkö, joka sisältää tarvittavan määrän putkilinjoja, joita pitkin kuuma vesi jaetaan tuotantotilaan. Pesijällä on mukanaan 
vain painepesurin pesukahva ja 10 m letkua. Putkilinjat sijoitetaan tuotantotilaan siten, että lyhyelläkin letkulla saadaan hyvä ulottuvuus pesukohteisiin. Ennen kuumavesipesuyksikön hankintaa, viljelijän kannattaa ottaa selvää riittääkö vesi ja tuleeko vettä riittävällä paineella verkosta. Veden paineeksi 3 bar ja veden tuotto 20 litraa minuutissa on riittävä (Tertsunen 2003a). Tertsusen (2003b) mukaan, kun sikalan korkeapainepesujärjestelmän runkoputkena käytetään haponkestävää 16*1,5 mm:n korkeapaineputkea, pesuveden lämpötila laskee 5-6 ${ }^{\circ} \mathrm{C}$ eristämättömillä vesiputkilla olettaen, että pesurin ja etäisimmän käyttöpisteen välimatka on enintään 100 m. Kiinteän pesujärjestelmän etu on sen käyttövalmius.

Sikalan pesuun voidaan käyttää myös pesurobottia. Robotin käyttö vähentää käsin tehtävää työtä 24-38 \%. Robotti liottaa ensin pestävän karkean lian ja se pystyy poistamaan liasta 80-86 \%. Veden kulutus on 11- 24 \% suurempaa kuin käsin pestäessä. Robotin käytön jälkeenkin on tehtävä loppupesu käsin (Larsson 2000). Larssonin (2000) mukaan robotti käytti vettä 834 - 621 litraa karsinaa kohden, pesuohjelmasta riippuen. Lisäksi vettä kului robotin tekemään liotukseen $375 \mathrm{l} /$ karsina $\left(8 \mathrm{~m}^{2}\right)$. Ilman liotusta robotti käytti pesuvettä 1110 litraa/karsina.

Larssonin (2000) mukaan eläintilan lattioiden liotus lämpimällä vedellä nopeuttaa lian irtoamista. Mitä lämpimämpi vesi, sitä nopeammin lika irtoaa. Liotuksessa veden kulutus on kuitenkin melko korkea, 375-640 l/karsina $\left(8 \mathrm{~m}^{2}\right)$.

Puhdistuksessa on tärkeää löytää tasapaino mahdollisimman vähäisen veden käytön ja riittävän hyvän pesutuloksen välillä. Vettä voidaan säästää myös seuraamalla veden kulutusta, korjaamalla vuotokohdat ja käyttämällä sadevettä soveltuvissa kohteissa (European comission 2003).

\subsection{Kuivuus ja siitä aiheutuvat ongelmat}

Kuivat kaudet vaikuttavat veden saatavuuteen laskemalla pohjavesien ja järvien pintoja sekä vähentämällä maan kosteutta. Kuivuus voi vaikuttaa pohjaveden määrään ja lisätä veden tarvetta maatalouden eri tuotantovaiheissa (Kampbell et al. 2003). Jos viljelijöillä ei ole vaihtoehtoista vesilähdettä käytettävissään, on veden käyttöä säännösteltävä (Gabriel \& Kreutzwiser 1993).

Kampbellin et al. (2003) tutkimuksen mukaan kuiva ajanjakso saattaa lisätä pohjaveden pilaantumisriskiä. He olivat verranneet ravinteiden määrää pohjavedessä ennen kuivaa ajanjaksoa ja sen aikana. Kuivana kautena kaivovedessä aikaisemmin pieninä pitoisuuksina olleet epäpuhtaudet saattavat väkevöityä. Tällaisia epäpuhtauksia ovat rauta, mangaani, fluoridi ja mikrobit. Kuivana aikana vesi imeytyy kaivoihin yhä syvemmistä maakerroksista. Syvemmissä maakerroksissa happipitoisuus voi olla alhaisempi kuin pintakerroksissa, joten kaivoveden happipitoisuus laskee. Tällöin maaperässä oleva rauta ja mangaani liukenevat helpommin veteen. Kuivana aikana myös pohjaveden virtausolosuhteet saattavat muuttua, jolloin kaivoon tulee vettä uudelta pohjavedenmuodostumisalueelta. Uudella alueella voi olla rautapitoinen tai saastunut maaperä, mistä saattaa aiheutua kaivoveden haittaainepitoisuuksien nousua (Keinänen 2003).

\subsubsection{Keinoja kuivuuden aiheuttamien ongelmien ratkaisuun}

Pitempiaikainen ratkaisu vesipulaan on rengaskaivon syventäminen tai porakaivon rakentaminen. Koska vesi loppuu aikaisemmin lähdekaivoista, otetaan kuivana aikana käyttöön syvempiä kaivoja normaaliaikoja enemmän. Jos rengaskaivosta loppuu vesi, väliaikainen ratkaisu on veden kuljetus muualta. 
Maatilojen halukkuus liittyä kunnalliseen vesijohtoverkkoon tai vesiosuuskuntaan on lisääntynyt kuivuuden ja veden puutteen seurauksena. Veden puute on myös nopeuttanut vesijohtoverkkojen laajentumista alueille, joissa niitä ei ole ollut aikaisemmin. Maaseudulla uusia vesiosuuskuntia on perustettu tai perusteilla lähes 30. Nykyinen vedenhankinta on oletettua haavoittuvampaa, kuten kuivuus on osoittanut (Silander \& Järvinen 2004).

\section{Tutkimusmenetelmät ja -aineistot}

\subsection{Kyselytutkimus}

Kyselytutkimus toteutettiin kirjekyselynä maatiloille maalis-huhtikuussa 2004. Kysely kohdistui keskimääräistä suuremmille tiloille. Kohderyhmäksi valittiin maidontuotantotilat, joilla oli yli 40 lypsylehmää, naudanlihantuotantotilat, joilla oli yli 100 nautaa, broilerinlihantuotantotilat, joilla oli yli 40000 lintua sekä yli 1000 lihasikapaikan tai yli 100 emakon sikatilat. Kyselytutkimus lähetettiin Varsinais-Suomen, Hämeen, Kaakkois-Suomen, Pohjois-Savon, Pohjanmaan sekä Pohjois-Pohjanmaan TE- keskusten alueilla sijainneille tiloille. Näillä alueilla harjoitetaan maataloutta intensiivisesti. Kyselyjä lähetettiin yhteensä 431 kappaletta, joista 5 naudanlihaa tuottaville tiloille, 20 broileritiloille, 136 sikatiloille ja 270 lypsykarjatiloille (Taulukko 4). Kyselykaavakkeet lähetettiin kaikille valitun kokoluokan tiloille lukuun ottamatta lypsykarjatiloja, joiden lukumäärää jouduttiin rajoittamaan siten, että samalla paikkakunnalla sijaitsevista tiloista karsittiin satunnaisotannalla joitakin pois.

Postikyselylomake sisälsi 46 kysymystä, joista osa oli avoimia ja osa monivalintakysymyksiä (Liite 1). Lomakkeen alkuosassa kartoitettiin maatilan päätuotantosuuntaa, käyttöveden lähdettä, tilan etäisyyttä lähimpään järveen, jokeen tai kunnalliseen vedenottamoon. Seuraavaksi kysyttiin maatilojen kaivoista, kaivojen iästä, syvyydestä, kaivoveden laadusta ja sen riittävyydestä sekä kaivon etäisyydestä mahdollisiin veden laadun riskitekijöihin. Lisäksi selvitettiin, oliko vuosien 2002 ja 2003 poikkeuksellinen kuivuus vaikuttanut veden määrään tai laatuun ja oliko kuivuus erityisesti aiheuttanut veden käyttörajoituksia. Lomakkeen lopussa kysyttiin maatilojen eläinten juomaveden ja tilojen pesuvesien käyttöä.

Palautetut vastauslomakkeet lajiteltiin tilatyyppien mukaisesti. Monivalintakysymysten vastaukset taulukoitiin Excel-tiedostoon ja avoimet kysymykset käsiteltiin erikseen. Jokaiseen kysymykseen vastanneiden lukumäärä laskettiin. Menetelmä on sama, jota Dolan et al. (2000) ovat käyttäneet omassa tutkimuksessaan. Jatkossa sulkeissa olevat prosentit ovat \%-osuuksia kuhunkin kysymykseen vastanneista.

Keväällä 2005 suoritettiin täydentävä puhelinkysely 13 sikatilalle ja seitsemälle maitotilalle. Tilat valittiin satunnaisesti postikyselyyn vastanneiden tilojen joukosta. Kyselyssä selvitettiin olivatko kesän ja syksyn 2004 sateet aiheuttaneet uusia veden laatu ongelmia, joita pitäisi ottaa huomioon kaivoveden käytössä. Tiloilta kysyttiin myös oliko kaivoon päässyt pintavesiä ja oliko vuoden 2004 aikana tapahtunut veden laadussa muutoksia. Lisäksi kysyttiin oliko kaivolle tehty viimeisen vuoden aikana korjaustoimenpiteitä ja oliko karjalle täytynyt kuljettaa vettä juomavedeksi mahdollisesti veden huonon laadun takia. Kysymykset olivat kyllä tai ei - kysymyksiä. 


\subsection{Pesukoe}

Kesällä 2005 suoritettiin MTT maatalousteknologian tutkimuksessa pesukokeet Clean HPS 1921T painepesurilla. Tavoitteena oli selvittää laboratorio-oloissa eläintilojen pesua. Pesurin pistoolissa oli kaksi suutinta, joista käytettiin joko yhtä tai kahta paineesta riippuen. Käytetyt pesupaineet olivat 60-180 bar. Painetta nostettiin kerrallaan 10 bar. Pesuria käytettiin minuutin ajan kullakin paineella. Käytön aikana mitattiin painepesurin veden, polttoaineen ja energian kulutusta sekä tuloveden lämpötilaa. Pesut tehtiin kolmena kerranteena. Tuloveden määrä ja lämpötila mitattiin Alfa Lavalin LKM PD 340-mittarilla. Jäljellä olevan polttoaineen määrää luettiin vaa’an näytöltä ennen jokaista pesukertaa. Polttoaineen tiheys määritettiin punnitsemalla yhden litran paino. Eri kokeena mitattiin pesurin tarvitsema sähköenergia ja pesurista tulevan pesuveden lämpötila kolmen minuutin jaksolla jokaisella paineella. Tehon mittaamiseen käytettiin kolmivaihekilowattituntimittaria, Valmet K4N. Pesuveden lämpötila mitattiin vesisuihkusta noin metrin etäisyydellä suuttimen kärjestä termometrillä. Tuloksista laskettiin keskiarvot jokaista painetta kohti.

\section{Tulokset ja niiden tarkastelu}

\subsection{Kyselytutkimus}

\subsubsection{Aineiston kuvaus}

Kyselykaavakkeita palautettiin $92 \mathrm{kpl}$, vastausprosentti oli 21. Vastaukset ryhmiteltiin alueisiin Etelä-Suomi, Länsi-Suomi ja Itä-Suomi. Taulukossa 4 on esitetty palautettujen kyselykaavakkeiden lukumäärät alueittain ja tilatyypeittäin sekä vastausprosentit. Vastausprosentti oli korkein Etelä-Suomen ja matalin Itä-Suomen lypsykarjatiloilla. Yksittäisiin kysymyksiin oli vastattu vaihtelevasti. Vastanneiden määrät on esitetty taulukossa 5. Joitakin kysymyksiä on taulukossa yhdistetty. Vastausprosentti 21 on melko alhainen, mutta kuitenkin hyväksyttävä. Postikyselyissä yleinen vastausprosentti on Neumannin (1997) mukaan 10-50 \% ja 20 \% on vielä hyväksyttävissä oleva (Nachmias \& Nachmias 1976). Tulokset antavat yleiskuvan vesilähteistä ja veden käytöstä. Matalan vastausprosentin vuoksi maantieteellisiä alueita ei ollut mahdollista verrata keskenään.

Taulukko 4. Vastausprosentit alueittain ja tuotantosuunnittain

\begin{tabular}{|c|c|c|c|c|c|c|c|c|c|c|c|c|}
\hline \multirow[b]{2}{*}{ Tuotantosuunta } & \multicolumn{3}{|c|}{ Etelä- Suomi } & \multicolumn{3}{|c|}{ Länsi-Suomi } & \multicolumn{3}{|c|}{ Itä-Suomi } & \multicolumn{3}{|c|}{ Yhteensä } \\
\hline & $\mathrm{kpl}$ & $\mathrm{kpl}_{1}$ & $\%$ & $\mathrm{kpl}$ & $\mathrm{kpl}_{1}$ & $\%$ & $\mathrm{kpl}$ & $\mathrm{kpl}_{1}$ & $\%$ & $\mathrm{kpl}$ & $\mathrm{kpl}_{1}$ & $\%$ \\
\hline Lypsykarjatila & 85 & 25 & 27 & 138 & 27 & 20 & 47 & 6 & 15 & 270 & 58 & 21 \\
\hline Lihakarjatila & 5 & 0 & 0 & - & - & - & - & - & - & 5 & 0 & 0 \\
\hline Sikatila & 71 & 19 & 27 & 52 & 6 & 12 & 13 & 3 & 15 & 136 & 26 & 19 \\
\hline Broileritila & 9 & 3 & 33 & 11 & 2 & 18 & - & - & - & 20 & 5 & 25 \\
\hline & & & & & & & & & & 431 & & 21 \\
\hline
\end{tabular}

$\mathrm{kpl}=$ Lähetetyt kyselylomakkeet

$\mathrm{kpl}_{1}=$ Saapuneet kyselylomakkeet

$\%=$ Vastausprosentti

- = ei lähetetty 
Kyselyyn vastanneiden tilojen päätuotantosuuntana oli 59 tilalla maidontuotanto, 28 tilalla sianlihantuotanto ja viidellä tilalla broilerintuotanto. Lihakarjatiloilta ei saatu vastauksia. Lypsykarjatiloista kymmenellä oli parsinavetta ja 48:lla pihatto sekä yhdellä tilalla molemmat. Lypsylehmiä kyselyyn vastanneilla tiloilla oli 50-100 ja vasikoita 15-80. Sikatiloista 10 oli emakko- tai yhdistelmäsikaloita sekä kahdeksan lihasikaloita. Tiloilla oli emakoita 95-300, vieroitettuja porsaita 260-700 ja lihasikoja 50-1 700. Broileritiloilla lintuja oli 45 000-60 000.

Pihatoissa ja parsinavetoissa oli suurimaksi osaksi kiinteä lattia. Sikaloissa oli yleisin täystai osaritilälattia (Taulukko 6). Kaikilla broileritiloilla oli kiinteä lattia, jolla käytettiin kuivikkeita.

Taulukko 5. Kirjekyselyn yksittäisiin kysymyksiin vastanneet tilat tuotantosuunnittain.

\begin{tabular}{|c|c|c|c|c|}
\hline $\begin{array}{ll}\text { Kysymys } & \text { Tuotantosuunta } \\
\end{array}$ & $\begin{array}{l}\text { Lypsykarjatila } \\
\mathrm{kpl}\end{array}$ & $\begin{array}{c}\text { Sikatila } \\
\mathrm{kpl}\end{array}$ & $\begin{array}{c}\text { Broileritila } \\
\mathrm{kpl}\end{array}$ & $\begin{array}{c}\text { Yhteensä } \\
\text { kpl }\end{array}$ \\
\hline Tilatyyppi & 59 & 28 & 5 & 92 \\
\hline Lattiatyyppi & 54 & 22 & 4 & 80 \\
\hline Eläinten määrä & 54 & 28 & 5 & 87 \\
\hline Tilan etäisyys lähimpään veden ottamoon & 30 & 14 & 1 & 45 \\
\hline $\begin{array}{l}\text { Tarve tai mahdollisuus liittyä } \\
\text { kunnalliseen vesijohtoverkostoon }\end{array}$ & 43 & 18 & 5 & 66 \\
\hline $\begin{array}{l}\text { Tilan etäisyys lähimpään } \\
\text { järveen/jokeen }\end{array}$ & 34 & 14 & 3 & 51 \\
\hline $\begin{array}{l}\text { Onko tilallanne käytetty järvi- tai } \\
\text { jokivettä }\end{array}$ & 41 & 18 & 0 & 59 \\
\hline Vesilähde & 59 & 28 & 5 & 92 \\
\hline Kaivotyyppi & 33 & 15 & - & 48 \\
\hline Kaivon syvyys & 33 & 13 & 2 & 48 \\
\hline Saanto & 19 & 6 & 1 & 26 \\
\hline Kaivon ikä & 31 & 12 & 3 & 46 \\
\hline Etäisyys mahdollisesta riskitekijästä & 34 & 16 & 2 & 52 \\
\hline Onko vedestä ollut pulaa & 45 & 21 & 5 & 71 \\
\hline Veden käyttörajoituksia & 44 & 19 & 5 & 68 \\
\hline Vettä kuljetettu muualta & 47 & 20 & 4 & 71 \\
\hline Vedestä tehty laatututkimus & 41 & 18 & 3 & 62 \\
\hline Veden laatuun vaikuttavat tekijät & 44 & 18 & 6 & 68 \\
\hline Kaivon kunnostaminen & 34 & 15 & 3 & 52 \\
\hline Eläinten juomavesi & 44 & 22 & 4 & 70 \\
\hline $\begin{array}{l}\text { Veden laadun tai määrän vaikutus eläin- } \\
\text { ten juomiseen }\end{array}$ & 42 & 18 & 2 & 62 \\
\hline Vaikutus tuotantoon & 28 & 11 & - & 39 \\
\hline Eläinten ulkoilumahdollisuus & 54 & 25 & 5 & 84 \\
\hline Vesi ulkona & 46 & 3 & 0 & 49 \\
\hline Tilojen pesutiheys & 51 & 26 & 1 & 78 \\
\hline Tilojen pesuvesimäärä & 57 & 10 & 5 & 72 \\
\hline Painepesuri & 52 & 25 & 5 & 82 \\
\hline $\begin{array}{l}\text { Lypsykoneputkiston pesussa } \\
\text { varastopesu }\end{array}$ & 50 & - & - & 50 \\
\hline Muu veden kulutus & 15 & 8 & - & 23 \\
\hline Kustannukset & 42 & 22 & 3 & 67 \\
\hline $\begin{array}{l}\text { Kiinnostus veden käytön } \\
\text { tehostamiseen }\end{array}$ & 47 & 16 & 4 & 67 \\
\hline
\end{tabular}


Taulukko 6. Tuotantorakennusten lattiatyypit navetta- ja sikalatyypeittäin

\begin{tabular}{lc|cc|r|r}
\hline & $\begin{array}{c}\text { Vastanneita } \\
\text { Kpl }\end{array}$ & $\begin{array}{c}\text { Täys- tai } \\
\text { osaritilä }\end{array}$ & Kiinteä & Ritilä + kuivike & Kiinteä + kuivike \\
\cline { 3 - 6 } & 7 & 42,9 & 57,1 & \multicolumn{4}{|c}{$\%$ vastanneista } \\
\hline Parsinavetta & 47 & 59,6 & 31.9 & 6,4 & 2,1 \\
\hline Pihatto & 7 & 57,1 & 14,3 & 28,6 & \\
\hline Emakkosikala & 6 & 83,3 & 16,7 & & \\
Lihasikala & 9 & 55,6 & 44,4 & & \\
Yhdistelmäsikala & 9 & &
\end{tabular}

Suurimmalla osalla tiloista etäisyys lähimpään kunnalliseen vedenottamoon oli 1 000$5000 \mathrm{~m}$ ja lähimpään järveen tai jokeen alle $1000 \mathrm{~m}$ (Kuva 1). Sikatilat, jotka olivat liittyneet kunnalliseen vesijohtoverkkoon, sijaitsivat lähempänä kunnallista vedenottamoa, kuin kunnallisen verkon ulkopuoliset sikatilat. Maitotilojen etäisyyksillä kunnalliseen vedenottamoon ja siihen liittymisellä ei havaittu olevan yhteyttä.

a)

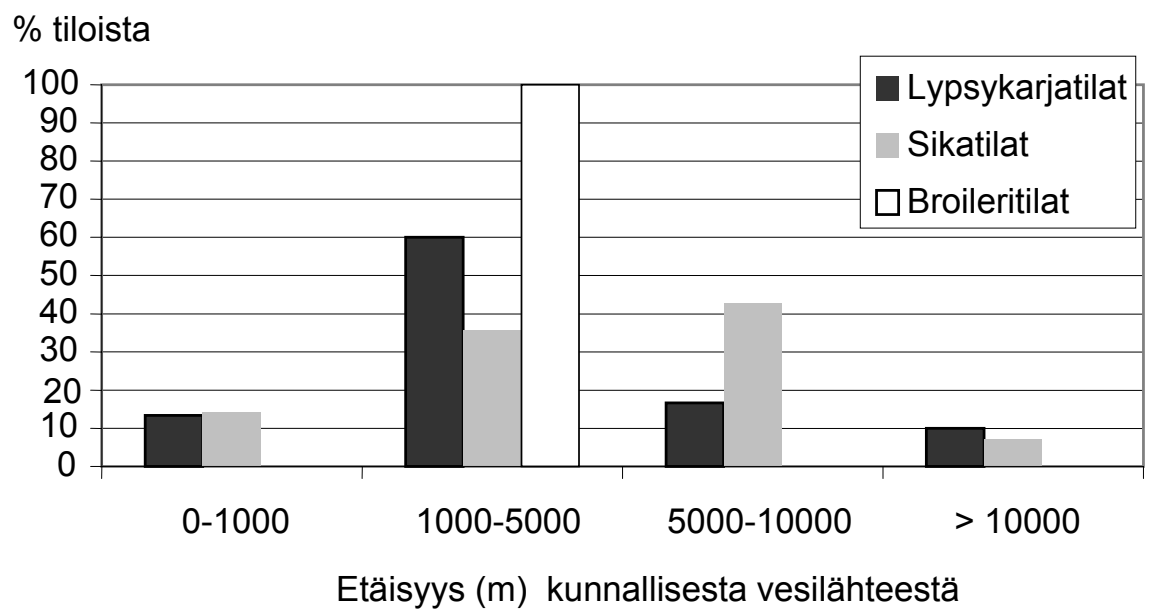

b)

$\%$ tiloista

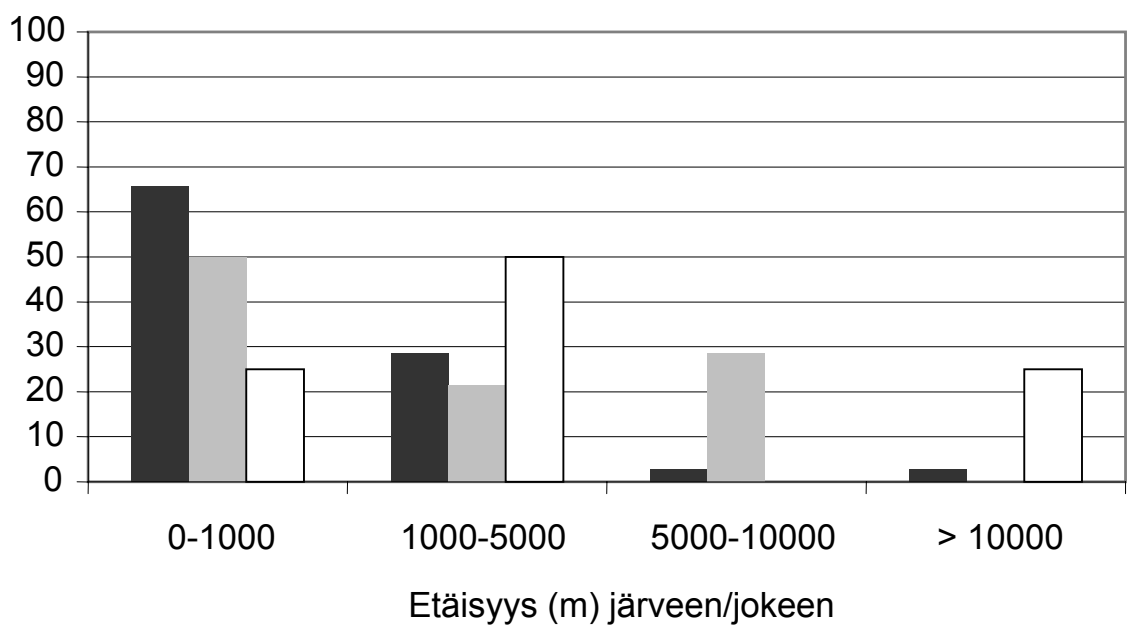

Kuva 1. Tilojen etäisyys kunnallisesta vedenottamosta (a) ja järvestä/joesta (b) 


\subsubsection{Käyttöveden lähde}

Suurimmalla osalla (64 \%) Etelä-Suomen lypsykarjatiloista oli käyttöveden lähteenä vain oma kaivo. Kunnallinen vesi oli varavesilähteenä usealla tilalla, vaikka käyttövetenä käytettiinkin oman kaivon vettä (Kuva 2). Länsi-Suomessa lypsykarjatiloista 33 \%:lla oli vain oma kaivo ja 48 \%:Ila oli sekä oma kaivo että kunnallinen vesi. Itä-Suomen lypsykarjatiloista 50 \% ottivat vetensä vain omasta kaivosta. Eri alueilla sijaitsevien sikatilojen käyttöveden lähteissä ei ollut merkittävää eroa.

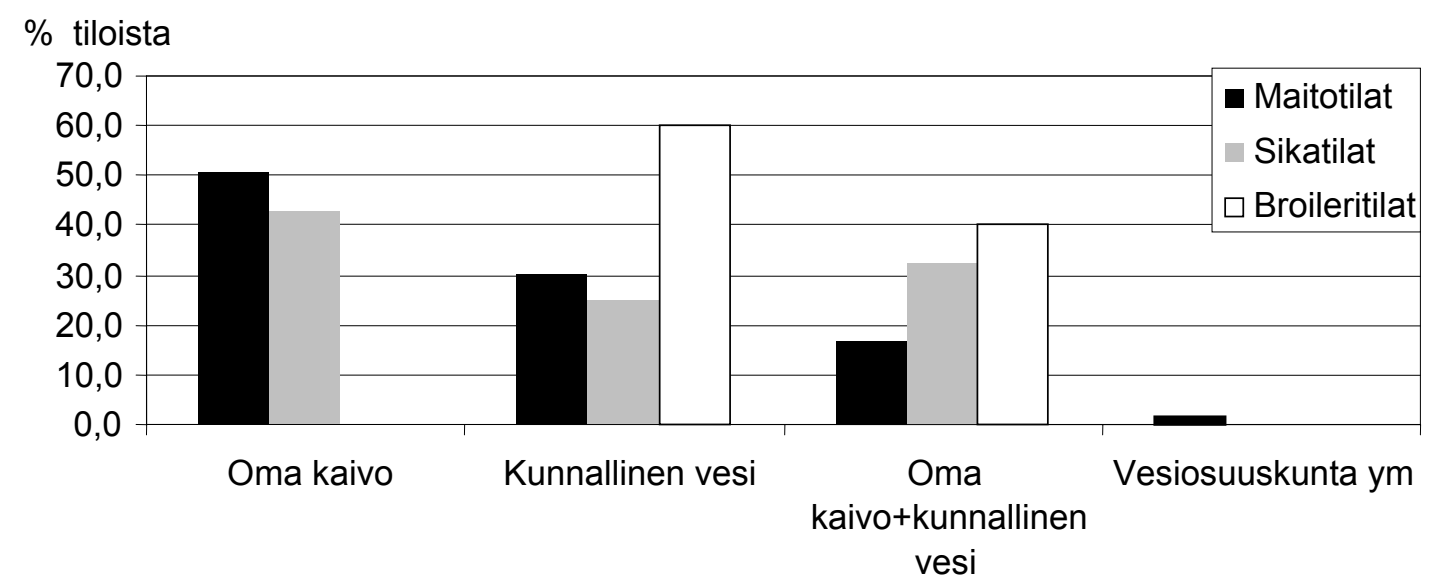

Kuva 2. Kotieläintilojen käyttöveden lähteet.

Rengaskaivoja oli kyselyyn vastanneiden tilojen kaivoista $39 \mathrm{kpl} \mathrm{ja} \mathrm{porakaivoja} \mathrm{29.} \mathrm{Monel-}$ la tilalla oli useita rengaskaivoja tai sekä rengaskaivo että porakaivo. Vain oman kaivoveden varassa olevista lypsykarjatiloista 50 \%:lla ja sikatiloista 42 \%:lla oli rengaskaivo. Rengaskaivojen saanto vaihteli 5 ja $200 \mathrm{~m}^{3} /$ vrk välillä ja syvyys vaihteli välillä 2 -12 metriä. Porakaivojen syvyydet olivat 21-202 m ja saanto $10-75 \mathrm{~m}^{3} / \mathrm{vrk}$. Kaivon syvyys vaikutti veden saantoon. Vanhimmat rengaskaivot oli rakennettu 1950-luvulla. Porakaivoja oli otettu käyttöön vasta 1970 - luvulta alkaen. Rengaskaivoja oli rakennettu 1950-1980 luvuilla enemmän kuin porakaivoja. Rakennettujen porakaivojen määrä ylitti rengaskaivojen määrän 1990-luvulla (Kuva 3). Suurin osa kaivoista oli rakennettu viimeisen 14 vuoden aikana.

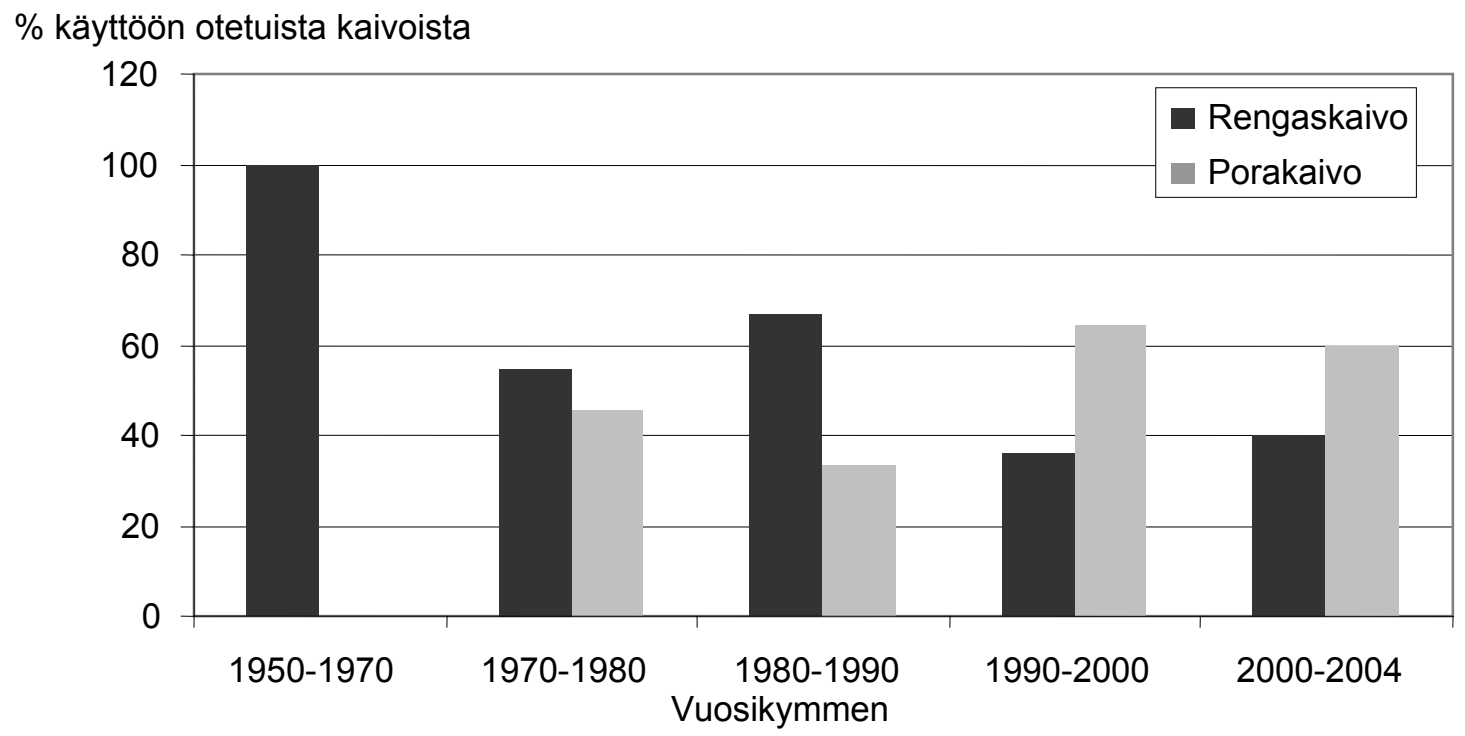

Kuva 3. Rengas- ja porakaivojen osuudet käyttöön otetuista kaivoista (rengaskaivoja 31 , porakaivoja 23) 


\subsubsection{Juoma- ja pesuveden kulutus}

Kyselytutkimukseen vastanneilla tiloilla juomaveden tarve riippui tilan eläinmäärästä sekä eläinten tuotantovaiheesta. Juomaveden kulutus oli maitotiloilla $1-10 \mathrm{~m}^{3} / \mathrm{vrk}$ ja sikatiloilla 2-8 $\mathrm{m}^{3} /$ vrk. Tilat ilmoittivat vuorokaudessa kuluvan juomaveden määrän yhteensä, ei eläinkohtaisesti. Ilmoitusten perusteella broileritilojen juomavedenkulutukseksi on laskettu vuorokaudessa 0,2-0,3 l/lintu. Eläinten ulkoilumahdollisuus oli maitotiloista 74 \%:lla ja sikatiloista 8 \%:lla. Suurimmalla osalla tiloista eläimet joivat samaa vettä ulkona ja sisällä. Tiloista 15 \% käytti eläinten juomavetenä normaalin käyttöveden lisäksi joki-, oja-, meritai järvivettä.

Tilojen välillä oli eroja pesuveden kulutuksessa sekä käytävien ja karsinoiden pesukertojen vuosittaisissa määrissä. Pesukertojen määrät vaihtelivat yhdestä kerrasta kuukaudessa yhteen kertaan vuodessa. Lypsyasemat ja maitohuoneet pestiin useimmiten kerran tai kaksi kertaa päivässä Pesuveden kulutus lypsykarja- ja sikatiloilla on esitetty taulukossa 7.

Taulukko 7. Kotieläintilojen pesuveden kulutus erilaisilla lattiatyypeillä

\begin{tabular}{|c|c|c|c|c|c|c|}
\hline & $\begin{array}{l}\text { Lattia- } \\
\text { tyyppi }\end{array}$ & $\begin{array}{l}\text { Koko } \\
\text { eläinsuoja } \\
\text { I/pesukerta }\end{array}$ & $\begin{array}{l}\text { Karsinat } \\
\text { I/pesukerta }\end{array}$ & $\begin{array}{l}\text { Käytävä } \\
\text { I/pesukerta }\end{array}$ & $\begin{array}{l}\text { Lypsy- } \\
\text { asema } \\
\text { I/vrk }\end{array}$ & $\begin{array}{l}\text { Maito- } \\
\text { huone } \\
\text { l/vrk }\end{array}$ \\
\hline \multirow{4}{*}{$\begin{array}{l}\text { Lypsy- } \\
\text { karjatila }\end{array}$} & Täysritilä & - & 200-1000 & $50-500$ & - & - \\
\hline & Osa ritilä & - & 2000 & - & - & - \\
\hline & Kiinteä & - & $20-5000$ & $20-5000$ & $50-1000$ & $10-200$ \\
\hline & $\begin{array}{l}\text { Kiinteä- } \\
\text { kuivike }\end{array}$ & - & $100-4000$ & - & - & - \\
\hline \multirow[t]{2}{*}{ Sikatila } & Täysritilä & $70000-84000$ & $2500-6000$ & - & - & - \\
\hline & Osa ritilä & 11000 & $200-900$ & - & - & - \\
\hline
\end{tabular}

Broileritilojen hallit pestiin kasvatuserien välillä 6-7 kertaa vuodessa. Vettä kului 5-40 m³ pesu. Eläintilojen pesuun kulutetun veden määrä riippui pesutavasta. Painepesuria koskevaan kysymykseen vastasi 82 tilaa. Kylmävesipesuri oli tiloista 66 \%:lla, kuumavesipesuri 57 \%:lla ja höyrypesuri 16 \%:lla, joten joillakin tiloilla oli käytössä useanlaisia pesureita. Kyselyyn vastanneiden tilojen kylmävesipesureiden käyttöpaineet olivat 120-210 bar, kuumavesipesurien 130-200 bar ja höyrypesureiden 180-200 bar.

\subsubsection{Veden laatu}

Tiloilla, jotka vastasivat kysymykseen kaivon etäisyydestä riskitekijään, oli yhteensä 30 rengaskaivoa ja 24 porakaivoa. Suurin osa kaivoista sijaitsi 100-500 metrin etäisyydellä maantiestä, lantavarastosta tai jätevesisäiliöstä. Kaivoista 31 \% sijaitsi 50 m säteellä eläinsuojasta ja $60 \%$ niistä sijaitsi alle 50 metrin etäisyydellä pellosta. Kuvassa 4 on esitetty erityyppisten kaivojen etäisyydet mahdollisista veden laatuun vaikuttavista riskitekijöistä.

Veden laatu oli tutkittu 13 rengaskaivosta, joista kahdeksassa (62 \%) oli löytynyt tekijä, joka ei täyttänyt sosiaali- ja terveysministeriön asettamia talousveden laatuvaatimuksia (STM 401/2001). Porakaivoja oli tutkittu 12. Niissä kaikissa oli jokin tekijä, joka ei täyttänyt talousveden laatuvaatimuksia. Kuvassa 5 on esitetty erityyppisten kaivojen vedessä havaitut laatupoikkeamien aiheuttajat. Veden laatua heikentävillä tekijöillä ei ollut vaikutusta eläinten juomaveden kulutukseen kolmea tilaa lukuun ottamatta. Näiden tilojen kaivoveden laatuun ei vaikuttanut pelkästään kuiva ajanjakso, vaan veden laatu on ollut jo aikaisemmin huono. Ne rengaskaivot, joiden veden laadussa oli todettu jokin sitä heikentävä tekijä, olivat 25-50 vuotta vanhoja ja syvyydeltään 2-4,5 metriä. 
a)

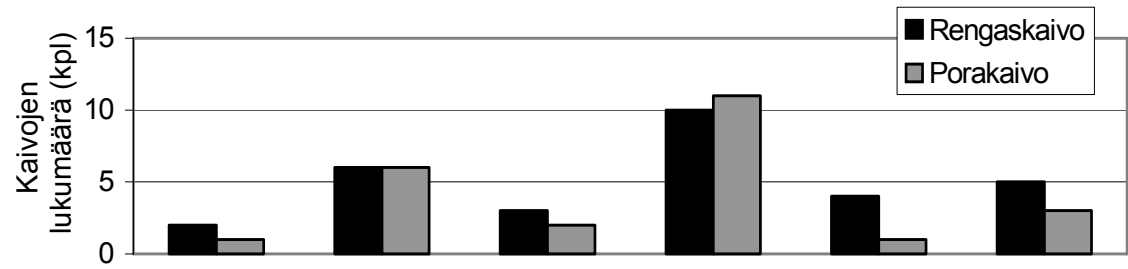

b)

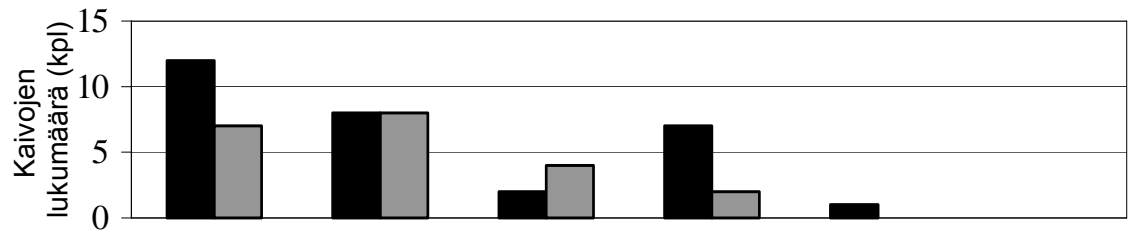

c)

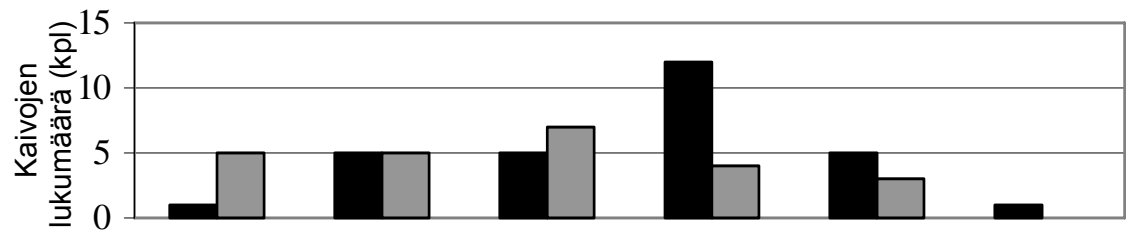

d)

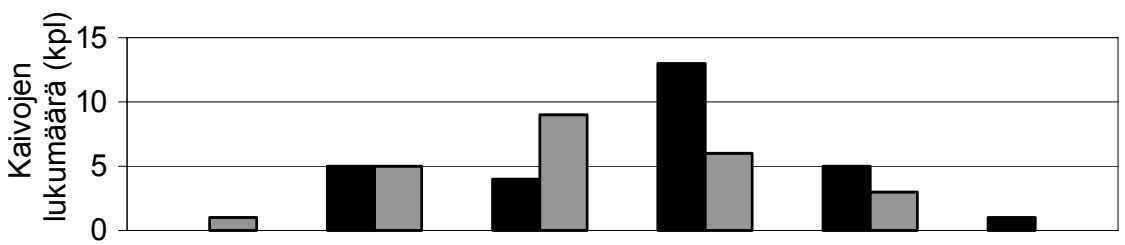

e)

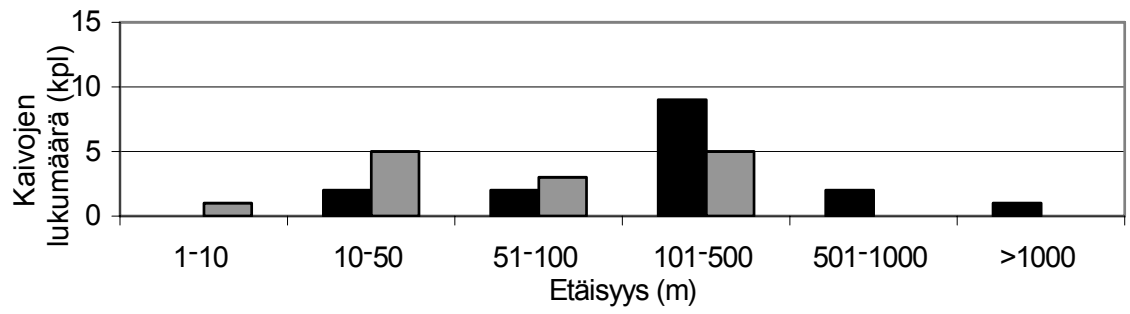

Kuva 4. Porakaivojen ja rengaskaivojen etäisyydet mahdollisista veden laatuun vaikuttavista riskitekijöistä a) maantie b) pelto c) eläinsuoja d) lantavarasto e) jätevesisäiliö.

\section{$\%$ tutkituista kaivoista}

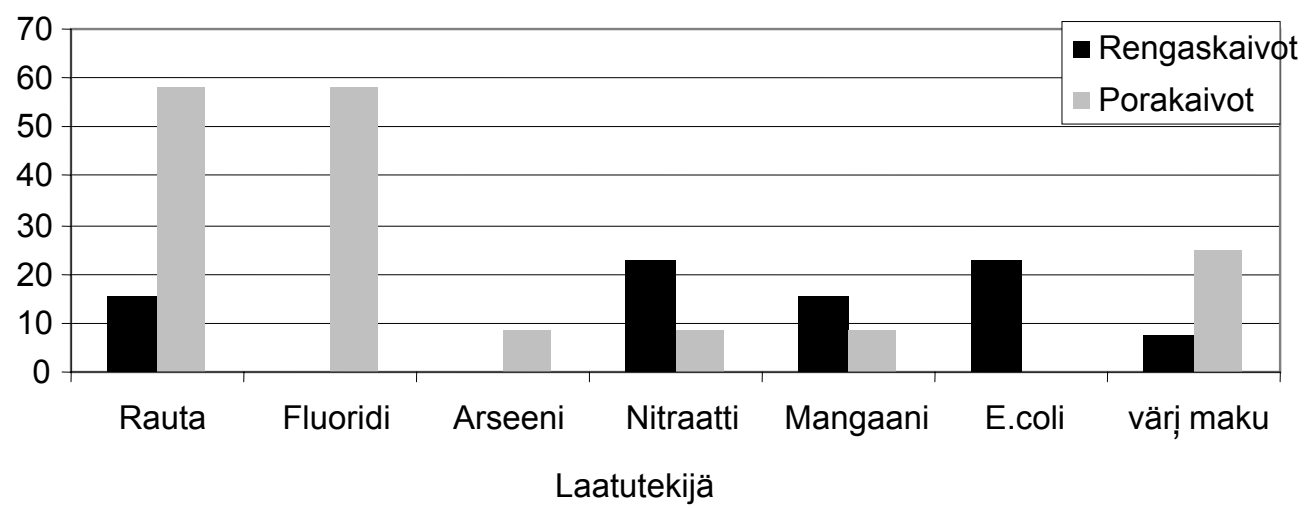

Kuva 5. Tutkituista kaivoista havaitut veden laatua heikentävät tekijät

Kyselytutkimuksen mukaan 58 \%:ssa tutkituista kaivoista fosforipitoisuus ylitti talousvedelle asetetun raja-arvon. Kyseiset kaivot sijaitsivat Etelä-Suomessa. 


\subsubsection{Veden riittävyys ja käytön tehostaminen}

Useilla tiloilla (lypsykarjatiloista 57 \%:lla ja sikatiloista 42 \%:lla) oli ollut vedestä pulaa vuosina 2002 ja 2003 tai aikaisemmin. Näistä lypsykarjatiloista $18 \%$ ja sikatiloista $16 \%$ oli joutunut myös rajoittamaan veden käyttöään. Säännöstelytoimenpiteinä olivat olleet esimerkiksi tuotantotilojen pesun vähentäminen sekä lehmien veden saannin rajoittaminen yön ajaksi. Eräillä tiloilla juomaveden rajoittamisella oli ollut negatiivinen vaikutus sekä tuotetun maidon määrään että laatuun. Tilat, joilla oli ollut vedestä pulaa jo ennen vuotta 2002, olivat ratkaisseet ongelman liittymällä kunnalliseen vesijohtoverkostoon.

Vettä oli kuljetettu kuivan jakson aikana Etelä-Suomen viidelle lypsykarja- ja kahdelle sikatilalle vuosien 2002 ja 2003 aikana. Kuljetettua vettä käytettiin eläinten juomavetenä, liemiruokkijassa ja maidonkäsittelylaitteiden pesussa. Tiloista $58 \%$ oli joutunut korjaamaan kaivojaan joko veden puutteen tai huonon laadun vuoksi. Näitä toimenpiteitä olivat vanhojen kaivojen kunnostus tai uuden kaivon tekeminen. Osa tiloista oli parantanut veden laatua poistamalla vedestä rautaa suodatuslaitteiston avulla.

Kyselyyn vastanneista tiloista 23 \% oli kiinnostunut veden käytön tehostamisesta tuotannossaan. Näistä suurin osa haluaisi käyttää varastopesua maitoputkiston ja lypsykoneen pesussa. Moni haluaisi käyttää uudelleen lypsylaitteiston pesuvesiä lattioiden pesussa. Vedenkäytön tehostamistavaksi mainittiin myös pintojen liotus ennen pesua. Sadevesien käyttömahdollisuudesta pintojen pesussa oltiin myös kiinnostuneita. Porakaivon rakentaminen oli ratkaissut useissa tapauksissa veden riittävyysongelman, mutta veden laadussa oli silti ongelmia. Kunnallisen vesihuollon piiriin tai vesiosuuskuntaan liittyminen oli ratkaissut monen tilan vesipulan. Useimmilla tiloilla käytettiin kunnan vettä vain osaan tilan toiminnoista tai sitä käytettiin vain tarvittaessa, jolloin se toimi varavesijärjestelmänä. Omista kaivoista saatavan veden määrää haluttiin lisätä ja veden laatua parantaa, jotta voitaisiin käyttää enemmän oman kaivon vettä ja säästää vesikustannuksissa. Suurin osa tiloista oli pärjännyt omin vesivaroin vaikka olivatkin osin joutuneet rajoittamaan veden käyttöä. Kuivat jaksot ovat opettaneet säästämään vettä. Maanviljelijät ovat kiinnostuneita vähentämään veden käyttöään varmistaakseen veden riittävyyden kaivoissa. Veden loppuminen aiheuttaisi tuotannon vähenemistä ja lisäkustannuksia (Dolan et al. 2000).

\subsubsection{Puhelinkyselyn tulokset}

Puhelinkyselyllä selvitettiin olivatko kesän ja syksyn 2004 sateet aiheuttaneet uusia ongelmia kaivoveden laatuun. Vastanneilla tiloilla ei pintavettä ollut päässyt kaivoon. Myöskään kaivoveden laadun ei ollut havaittu muuttuneen aikaisemmasta. Runsaat sateet eivät siten olleet vaikuttaneet tilojen kaivoveden laatuun. Viimeisen vuoden aikana ei tiloilla oltu myöskään tehty kunnostuksia kaivon rakenteissa. Kyselyyn vastanneiden tilojen kaivojen rakenteet olivat ilmeisen hyvät.

\subsection{Pesukoe}

Painepesuriin tulevan veden lämpötila oli $11-15^{\circ} \mathrm{C}$. Koska ulkolämpötila oli heinäkuussa $20-25{ }^{\circ} \mathrm{C}$, tuloveden lämpötila nousi letkussa matkalla pesuriin. Taulukossa 8 on esitetty pesukokeen tulokset pestäessä yhdellä suuttimella. Yhdellä suuttimella pestäessä pesurin painetta nostettiin tasaisesti kymmenellä yksiköllä 60 ja 180 bar välillä. Paineen ollessa 60 bar pesuveden lämpötila oli korkein ja veden sekä sähköenergian kulutus pienin. 
Kahdella suuttimella pestäessä painetta ei voitu nostaa 80 baria korkeammaksi. Pesuissa pesuveden kulutus oli 18-21 l/min, eli veden kulutus oli hieman suurempaa kuin käytettäessä yhtä suutinta ja vastaavia paineita. Pesuveden lämpötila kahdella suuttimella oli 60 $67^{\circ} \mathrm{C}$ ja sähkön kulutus 3-3,6 kWh.

Taulukko 8. Painepesurin paineen vaikutus pesuveden lämpötilaan sekä sähkön, veden ja polttoaineenkulutukseen yhdellä suuttimella pestäessä.

\begin{tabular}{lccccc}
\hline Paine & $\begin{array}{c}\text { Sähkön } \\
\text { kulutus } \\
\text { kWh }\end{array}$ & $\begin{array}{c}\text { Pesuveden } \\
\text { lämpötila } \\
{ }^{\circ} \mathrm{C}\end{array}$ & $\begin{array}{c}\text { Veden kulutus } \\
\text { bar }\end{array}$ & $\begin{array}{c}\text { Polttoaineen kulutus } \\
\mathrm{kWh}\end{array}$ & $\mathrm{g} / \mathrm{min}$ \\
\hline 60 & 3,2 & 94 & 10,7 & 94 \\
70 & 3,5 & 85 & 11,8 & 94 \\
80 & 3,9 & 85 & 13,7 & 101 \\
90 & 4,3 & 80 & 13,5 & 102 \\
\hline 100 & 4,7 & 76 & 14,5 & 102 \\
130 & 5,8 & 72 & 16,6 & 103 \\
140 & 6,1 & 71 & 17,3 & 138 \\
150 & 6,6 & 69 & 18 & 108 \\
160 & 6,8 & 64 & 18,7 & 101 \\
170 & 7,0 & 62 & 19,2 & 112 \\
180 & 7,4 & 63 & 19,8 & 99 \\
\hline
\end{tabular}

Painepesurissa käytetyn polttoaineen tiheydeksi saatiin $840 \mathrm{~g} /$, ulkolämpötilan ollessa $22{ }^{\circ} \mathrm{C}$. Tällöin polttoaineen kulutus oli yhdellä suuttimella pestäessä $90-110 \mathrm{~g} / \mathrm{min}$ ja kahdella $100-120 \mathrm{~g} / \mathrm{min}$.

Puumalan ym. (2005) tutkimuksessa, jossa oli pesty 80 barin paineella eri materiaaleilla pinnoitettuja betonikappaleita, pintakäsittelyistä riippuen pesun työsaavutus on ollut 162$648 \mathrm{~m}^{2} / \mathrm{h}$. Tulosten mukaan veden kulutus kyseisellä paineella oli $822 \mathrm{l} / \mathrm{h}$. Vettä kului siis $1,2-5 \mathrm{l} / \mathrm{m}^{2}$.

\section{Johtopäätökset}

Kaivoveden laatuun vaikuttavat maa- ja kallioperän koostumus sekä kaivon läheisyydessä olevat riskitekijät. Kallioperässä olevat alkuaineet, mm. rauta, fluori ja arseeni, voivat liueta veteen ja siten niitä voidaan havaita myös kaivovedessä. Myös lähistöllä olevat pellot, maantiet, eläinsuojat ja jätevesisäiliöt voivat vaikuttaa veden laatuun. Kaivon oikealla sijoittelulla voidaan huomattavasti vaikuttaa käyttöveden laatuun. Kaivon sijoituspaikan valinta antoisuuden perusteella on hankalaa, vaikka kaukokartoituksella, ruhjetulkinnoilla ja seismisellä luotauksella saantoa voidaan ainakin periaatteessa arvioida. Pintavettä voidaan käyttää pesuvedeksi, mutta eläinten juomavetenä sen käyttö onnistuu varmimmin alkukesästä. Loppukesällä pintavesiin saattaa muodostua leväesiintymiä, jolloin vesi voi muuttua eläimille juomakelvottomaksi. 
Kirjekyselyn vastausprosentti oli suhteellisen alhainen, mikä rajoitti joidenkin johtopäätösten tekoa. Kaikissa kysymyksissä eri tuotantosuuntia ei pystytty käsittelemään omina ryhminään ja esim. eri alueiden välillä voitiin verrata toisiinsa vain käyttöveden lähteitä. Etelä- ja Itä-Suomessa lypsykarjatilat tulivat pääsääntöisesti toimeen oman kaivon vedellä, kun taas Länsi-Suomessa vain joka kolmas lypsykarjatila oli pelkästään oman kaivon varassa. Yleisimpänä pää- tai varavesilähteenä länsisuomalaisilla tiloilla oli kunnallinen vesijohtoverkosto. Suurimmalla osalla kotieläintiloista, jotka olivat vain oman kaivoveden varassa, ei ollut ongelmia veden riittävyydessä kuivanakaan ajanjaksona. Sikatiloilla ei tällaista alueittaista vaihtelua ollut havaittavissa. Broileritilat sen sijaan olivat pääsääntöisesti liittyneet kunnalliseen vesijohtoverkostoon.

Suurimmalla osalla tiloista kaivoveden laatua ei oltu tutkittu. Vedenlaatututkimus oli tehty vain 25 kaivosta, kun kaivoja kaikkiaan oli 68. Suurimmassa osassa tutkituista kaivoista veden laatu ei täyttänyt talousvedelle asetettuja laatuvaatimuksia. Porakaivoissa laatuvirheet olivat yleisempiä kuin rengaskaivoissa. Koska kaivojen kuntoa, sijaintia tai rakennetta ei kyselyillä selvitetty tarkasti, veden laatuvirheiden syitä ei pystytty erittelemään.

Maatiloilla vettä kului eniten eläinten juomavedeksi, joten hyvälaatuisen talousveden saanti ja riittävyys on maatiloille elintärkeää. Seuraavaksi eniten vettä kului eläintilojen pesuun. Siihen tarvittava vesimäärä riippuu käytettävästä kalustosta (kylmä-, kuuma tai höyrypesuri) ja pesutavasta. Kyselyn tuloksena saadut juoma- ja pesuvesien käyttömäärät ovat arvioita. Mikäli eläinkohtaisia juomavesimääriä tai käytetyn pesuveden määrää halutaan selvittää tarkemmin, on kulutus mitattava.

Pesuveden säästötapoja on monia. Lypsykarjatiloilla voidaan säästää vettä käyttämällä lypsykoneputkiston pesuvesiä uudelleen eläintilojen pesuun tai kierrättämällä pesuvettä laitteen pesussa.

Tutkimus osoitti, että suurehkot tilat olivat pääsääntöisesti ratkaisseet veden riittävyysongelman. Selviytymiskeinot olivat samoja kuin kirjallisuudessa esitetyt. Sen sijaan veden laatuvirheitä esiintyi lähes kaikilla (80 \%) kaivovetensä analysoinneilla tiloilla. Laatuvirheisiin veden säästötoimenpiteillä ei ollut vaikutusta. Toisaalta runsaat sateet eivät olleet heikentäneet kaivoveden laatua, mistä voidaan päätellä, että tiloilla rengaskaivojen rakenteet olivat ehjiä.

Kun painepesurissa käytetään alhaista painetta, pesuveden lämpötila saadaan korkeaksi, jopa höyrystymislämpötilaan. Pientä painetta käytettäessä veden kulutus on alhaisin. Veden kulutus aikayksikössä kasvaa paineen noustessa. Toisaalta myös pesunopeus, jota tässä tutkimuksessa ei selvitetty, kasvaa paineen noustessa. Kirjallisuuden perusteella maanviljelijöiden tulisi käyttää korkeapainepesureita säästääkseen vettä. Haastattelutilojen käyttämissä kuumavesipesureissa käyttöpaine oli 130-200 bar. Pesukokeen mukaan näillä paineilla painepesurin veden kulutus oli 16-20 litraa minuutissa ja pesuveden lämpötila 60-70 ${ }^{\circ} \mathrm{C}$. Pesukoe antaa kuvan vain yhden pesurin vedenkulutuksesta. Eläintilojen pesussa tärkeää on myös hygienia, jota tässä tutkimuksessa ei otettu huomioon. Mahdollisimman pienellä vedenkulutuksella ei saada välttämättä riittävän hyvää puhdistustulosta. 


\section{Kirjallisuus}

Agronet 2005. Rakennukset ja ympäristö. Juomalaitteet. Saatavissa internetistä: http://www.agronet.fi/mkl/20/juomalaitteet. Viitattu 23.12.2005.

Dolan, A.H., Kreutzwiser, R.D. \& de Loë, R.C. 2000. Rural Water Use and Conservation in Southwestern Ontario. Journal of Soil and Water Conservation. 5(2), 161-171.

European Commission 2003. Integrated Pollution and Prevention and Control (IPCC). Reference Document on Best Available Techniques for Intensive Rearing of Poultry and Pigs. p. 107-108.

Fulhage, C.\& Hoehne, J. 2005. Considerations in Sizing Manure Storage Facilities. Lesson 21: Sizing Manure Storage, Typical Nutrient Characteristics. Saatavissa internetistä: http://www.lpes.org/Lessons/Lesson21/21_2_sizing_storage.pdf. Viitattu 23.11.2005.

Gabriel, A.O. \& Kreutzwiser, R.D. 1993. Drought hazard in Ontario: A review of impacts, 19601989, and management implications. Canadian water resources journal 18(2), 117-132.

Gadberry, S. 2000. Water for Beef Cattle. University of Arkansas. Division of Agriculture. FSA3021PD-10-04R, 4 p.

Goss, M.J., Barry, D.A.A.J. \& Rudolph, D.L. 1998. Contamination in Ontario farmstead wells and its association with agriculture: 1 . Results from drinking water wells. Journal of contaminant hydrology $32,267-293$.

Hallberg, G.R. \& Kross, B.C. 1990. lowa Statewide Rural Well Water Survey - Summary of the results. lowa State University. University extension, Ames, lowa. 4 p.

Helminen, J., Manninen, E., Mattila, E., Niskanen, H., Pankakoski, M., Vaara, R., Laine, H. \& Vuorinen, L. 1998. Maitotilan jätevedet. Valion alkutuotannon ja jäsensuhteiden julkaisuja n:ro 2/98, $46 \mathrm{~s}$.

Hellstén, P., Nystén, T., Kokkonen, P., Valve, M., Laaksonen, T., Määttä, T. \& Miettinen, I. 2002. Vaihtoehtoisten liukkaudentorjunta-aineiden kulkeutuminen pohjaveteen. Suomen ympäristökeskus. Suomen ympäristö 552.

Hörnig, G. \& Scherping, E. 1995. Water Consumption and the Amount of Waste Water Generated in Milking Plants and Dairy Houses of Large Dairy Cattle Farms. Zemedelska Technika, 41(1), 29-34.

IImatieteenlaitos 2005. Vuositilastot. Saatavissa internetistä: http://www.fmi.fi/saa/tilastot_99.html\#6. Viitattu 22.11.2005.

Irwin, R.W. 1986. Water Requirements of Livestock. Ministry of agriculture Food and Rural Affairs. Factsheet Agdex 400/716. 4 pp.

Kallio, J. \& Santala, E. 2002: Maitohuoneen jätevesien käsittely. Ympäristöopas 91. Vammalan kirjapaino Oy, Vammala. $84 \mathrm{~s}$. Saatavissa internetistä: www.vyh.fi/palvelut/julkaisu/elektro/yo91/yo91.htm.

Kampbell, D.H., An, Y.-J., Jewell, K. P. \& Masoner, J.R. 2003. Groundwater quality surrounding Lake Texoma during short-term drought conditions. Environmental Pollution 125, 183-191.

Kansanterveyslaitos 2003. Kansallinen ympäristöterveysohjelma. Vesivarat. Saatavissa internetistä: http://www.ktl.fi/ymparisto/3_1_vesi.htm. Luettu 24.4.2003.

Kapuinen P \& Karhunen, J. 1990: Lietelantajärjestelmien toimivuus. Vakolan tutkimusselostus 59 ISSN 0782-0054. 
Keinänen, J. 2003. Kuivuus ja talousveden laatu. Ympäristö ja terveys -lehti 5: 34-35.

Korkeamäki, A., Manninen, E. \& Nyman, K. 2003. Lypsykoneen ja tilasäiliön pesuvesien uudelleenhyödyntämisjärjestelmät: suosituksia käytännön kokemusten pohjalta. $7 \mathrm{~s}$.

Korkka-Niemi, K. 2001. Cumulative geological, regional and site-specific factors affecting groundwater quality in domestic wells in Finland. Monographs of the Boreal Environment research 20. Saaavissa internetistä: http://www.ymparisto.fi/download.asp?contentid=13364\&lan=EN Viitattu 28.2.2003.

Kotkasaari, T. 2003. Vesitalouden merkitys kasvaa. Luonnonvara 6/2003. 3 s.

Lahermo, P., Tarvainen, T., Hatakka, T., Backman, B., Juntunen, R., Kortelainen, N., Lakomaa, T., Nikkarinen, M., Vesterbacka, P., Väisänen, U. \& Suomela, P. 2002. Tuhat kaivoa - niiden hankinnasta ja käytöstä aiheutuvat kustannukset. Suomen kaivovesien fysikaalis-kemiallinen laatu vuonna 1999. Geologian tutkimuskeskus. $92 \mathrm{~s}$.

Lapinlampi, T., Sipilä, A., Hatva, T., Kivimäki, I., Kokkonen, P., Kosunen, J., Lammila, J., Lipponen, A., Santala, E. \& Rissanen, J. 2001. Kysymyksiä kaivoista. Suomen ympäristökeskus. Ympäristöopas 86: $154 \mathrm{~s}$.

Larsson, K. 1997. Utvärdering av vattenventil till slaktsvin. JTI-rapport Lantbruk \& industry no 239, $28 \mathrm{~s}$.

Larsson, K. 2000. Rengöring av svinstall. Cleaning of pig-houses (English Summary). JTI-rapport Lantbruk \& industry no 266,49 s.

Lybeck, C., Hulkkonen, H. \& Närhinen,T. 2004. Maaseutuyritysten vesihuolto ja elintarviketurvallisuus. Mikkelin kaupungin julkaisuja 1/2004, 93 s.+ 9 liitettä.

MMM 2002. MMM:n asetus nro 8/EEO/2002 Saatavissa internetistä: http://www.mmm.fi/el/laki///k15fi.pdf Luettu 20.2.2003.

Nachmias, D. \& Nachmias, C. 1976. Research methods in the Social Sciences. New York St. Martins Press.

Neuman, L.W. 1997. Social research methods: Qualitative and quantitative approaches. $3^{\text {rd }}$ ed. Boston Allyn Bacon.

Petersson, J. 2002. Mjölkningsrobotar Höga betyg på service och teknik. Husdjur 11/2002 s. 8-20.

Piirainen, T. 2004. Vesihuolto haja-asutusalueilla. Ympäristö- ja terveyslehti. Talousvesi-teema, 35, s. $57-64$.

Puumala, M., Jauhiainen, P., Mattila, T., Kaustell, K., Komonen, J., Kymäläinen, H-R., Norring, M., Sjöberg, A-M., Suutarinen, J. \& Valros, A. 2005. Kotieläinrakennusten lattioiden pinnan laatu hankkeen loppuraportin käsikirjoitus. Julkaisematon.

Rath, K.C. 2000. Comparison of aqua globe bite ball valves vs. conventional drinkers. Swine housing: proceedings of the first international conference. Des moines, lowa, USA 9-11 October, 2000. p. 118-119.

Rissanen, J. (toim.) 1999. 100 kysymystä levistä. Suomen ympäristökeskus. Ympäristöopas 63: 88 s.

Silander, J. \& Järvinen, A.(toim.) 2004. Vuosien 2002-2003 poikkeuksellisen kuivuuden vaikutukset. Suomen ympäristö $731,71 \mathrm{~s}$.

STM 2001. Asetus 401/2001 Pienten yksiköiden talousveden laatuvaatimuksista ja valvontatutkimuksista. Saatavissa internetistä:

http://www.finlex.fi/lains/smurkortti2.php?numero=401\&vuosi=2001\&sivu=0. Viitattu 18.2.2003. 
Suomen ympäristökeskus 2002. Arseeni pohjavedessä. Päivitetty 22.8.2002 Saatavissa internetistä: http://www.ymparisto.fi/default.asp?contentid=22868\&lan=fi. Viitattu 21.10.2003.

Suomen ympäristökeskus 2004a. Hydrologinen yleiskatsaus 2003. Päivitetty 23.4.2004. Saatavissa internetistä: http://www.ymparisto.fi/default.asp?contentid=75056\&lan=Fl. Viitattu 24.4.2004.

Suomen ympäristökeskus 2004b. Pohjaveden kloridipitoisuudet ensimmäisen Salpausselän alueella. Saatavissa internetistä: http://www.ymparisto.fi/default.asp?node=7200\&lan=FI. Viitattu 6.4 .2004

Suomen ympäristökeskus 2004c. Arseenin poisto. Saatavissa internetistä: http://www.ymparisto.fi/default.asp?contentid=41638\&lan=Fl. Viitattu 22.12.2005

Suomen ympäristökeskus 2004d. Raudan ja mangaanin poisto. Saatavissa internetistä http://www.ymparisto.fi/default.asp?contentid=51774\&lan=fi\#a0. Viitattu 16.01.2006.

Suomen ympäristökeskus 2005a. Hydrologinen yleiskatsaus 2004. Saatavissa internetistä. http://www.ymparisto.fi/default.asp?contentid=128295\&lan=fi. Viitattu 21.12.2005

Suomen ympäristökeskus 2005b. Pohjavesi. Päivitetty Saatavissa internetistä: http://www.ymparisto.fi/default.asp?node=107\&lan=fi. Viitattu 9.12.2005.

Sæther, O.M., Reinmann,C. \& Hilmo, B.O. 1995. Chemical Composition of Hard- and Softrock Groundwaters from Central Norway with Special consideration of Fluoride and Norwegian Drinking Water Limit. Environmental Geology 26, 147-156.

Tertsunen, V. 2003a. Keskitettyä kuumavesipesua. Maatilan Pirkka 3, s. 48.

Tertsunen, V. 2003b. Kuuma keskuspesu antaa lialle kyytiä. Maatilan Pellervo, s. 47.

Tiehallinto 2004. Pohjaveden suojaus tien kohdalla. Suunnitteluvaiheen ohjaus. Edita, Helsinki. Saatavana internetistä: http://alk.tiehallinto.fi/thohje/pdf/2100028-v-04pohjavsuojtienkohd.pd.pdf. Viitattu 9.1.2006.

Säteilyturvakeskus 2003. Saatavissa internetistä: http://www.sateilytyuvakeskus.fi/ Viitattu 5.12.2003.

Varsinais-Suomen Agenda 21 2004. Kaivotietoa II-osio. Saatavissa internetistä: http://www.vsagendatoimisto.fi/vesiensuojelu/haja-asutuksen_vedenhankinta/kaivo/kaivotietoa_ paketti_kaivoosuus.htm. Viitattu 9.12.2005.

Virta, P. 2002. Tuotantoeläin tarvitsee aina puhdasta vettä. Maatilan Pellervo. Saatavissa internetistä: http://www.pellervo.fi/maatila/mp5_02/piiavirta.htm. Viitattu 20.2.2003.

VN 931/2000. Valtioneuvoston asetus maataloudesta peräisin olevien nitraattien vesiin pääsyn rajoittamisesta 931/2000.

Zimmerman, A., Veira, D., von Keyserlingk, M., Weary, D. \& Fraser, D. 2002. Water Quality Affects Cattle Drinking Behaviour and Consumption. Dairy education \& research centre, The University of British Columbia, Canada. Research reports 2 (9), 4 p.

Ympäristöministeriö 1998. Ohje kotieläintalouden ympäristönsuojelusta 30.9.1998.

Saatavana internetistä: http://www.vyh.fi/palvelut/julkaisu/elektro/maaseutu/kotiel.pdf. 


\section{Kysely kunnallisen vesihuollon ulkopuolisille maatiloille}

\section{Vastatkaa rastittamalla oikea vaihtoehto ja/tai vastaamalla kysymykseen.}

Kuuluuko tilanne kunnallisen vesihuollon piiriin (rasti ruutuun)
$\square$ Kyllä (Täyttäkää kohdat $1-5$ ja siirtykää kohtaan 30 )
$\square \mathrm{Ei}$
Tilalla on sekä oma kaivo että kunnallinen vesijohto.

Vastaajan nimi

Puhelin

\section{Paikkakunta}

Olemme kiinnostuneet osallistumaan tarkempaan vedenkäyttöselvitykseen.

$\square$ Kyllä $\square$ Ei

\section{Tiedot tuotantotilasta}

\section{Tilan päätuotantosuunta}

$\square$ Maidontuotanto

Sianlihantuotanto

Naudanlihantuotanto

Broilerinlihantuotanto

$\square$ Kasvintuotanto

Muu, mikä

2. Mahdollinen sivutuotanto

$\square$ Jatkojalostus, minkä?

Avomaan vihannesviljely

Muu, mikä?

3. Tuotantotilan tyyppi

Sikalatyyppi

$\square$ Emakkosikala

Lihasikala $\quad \square$ Yhdistelmäsikala

Navettatyyppi

$\square$ Parsinavetta

Pihatto

Muu, mikä?

4. Tuotantotilan lattiatyyppi

$\square$ Kiinteä $\square$ Ritilä koko/osa $\square$ Kuivikepohja $\square$ Muu, mikä?

5. Tilan eläinten/eläinpaikkojen määrä

Emakot

Vasikat Lihasiat Lihanaudat
Lypsylehmät

Muuta, mitä

\section{Tiedot kaivosta}

6. Tuotantotilan veden lähde

7. Kaivotyyppi

$\square$ Rengaskaivo

$\square$ Porakaivo

$\square$ Muu, mikä

8. Kaivon etäisyys

$\square$ Maantiestä m

Lantavarastosta $\mathrm{m}$

$\square$ Oma kaivo $\square$ Muu, mikä

Syvyys, $\mathrm{m} \quad$ Saanto $\mathrm{m}^{3} / \mathrm{vrk} \quad$ Rakennusvuosi
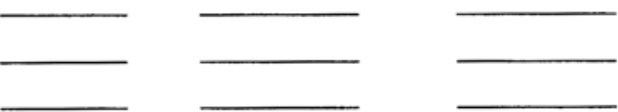

9. Onko kaivonne lähellä jokin muu kohde, joka saattaa vaikuttaa kaivoveden laatuun? Mikä

Viljellystä/lannoitetusta pellosta

Eläinsuojasta $\mathrm{m}$ Etäisyys $\mathrm{m}$

10. Tutkitaanko kaivon vesi säännöllisesti?

Kyllä, miten usein? $\square \mathrm{Ei}$ 


\section{Tiedot veden saatavuudesta ja riittävyydestä}

11. Onko tilanne tärkeällä pohjavesialueella?

$\square$ Kyllä $\square \mathrm{Ei}$

12. Tilanne etäisyys lähimmästä vedenottamosta $\mathrm{m}$

13. Onko tilallanne ollut ongelmia veden riittävyydessä vuosina 2002 - 2003?

$\square$ Kyllä $\square$ Ei

14. Onko tilallanne ollut ongelmia veden riittävyydessä aikaisemmin?

Kyllä, milloin?

15. Oletteko havainneet selvästi kuivan jakson vaikutukset vesihuollossanne?

Kyllä, miten?

16. Onko veden käyttöä pitänyt rajoittaa tai tehostaa?

Kyllä, miten?

17. Onko tilallenne jouduttu kuljettamaan vettä muualta?

Kyllä $\square \mathrm{Ei}$

18. Vettä on tuotu muualta

Jatkuvasti tietyn ajanjakson, milloin?

Satunnaisesti kertaa/vuosi

$\square$ Yhdellä kertaa kuljetettava vesimäärä $\mathrm{m}^{3}$

19. Mihin olette käyttäneet muualta tuotua vettä?

Eläinten juomavetenä $\square$ Maitoputkiston/tankin pesussa $\square$ Muu käyttö, mikä?

20. Onko tilallanne käytetty/käytetäänkö esim. joki- tai järvivettä?

$\square$ Kyllä $\square \mathrm{Ei}$

21. Tilanne etäisyys lähimmästä järvestä/joesta $\mathrm{m}$

22. Onko tilallanne ollut tarvetta liittyä kunnalliseen vesihuoltoon?

$\square$ Kyllä $\square$ Ei

23. Onko tilallanne ollut mahdollisuutta liittyä kunnalliseen vesihuoltoon?

Kyllä $\square \mathrm{Ei}$

\section{Tiedot veden laadusta}

24. Onko käyttövetenne laatu poikennut sosiaali- ja terveysministeriön antamista talousvedelle asetetuista laatuvaatimuksista?
Kyllä
$\square \mathrm{Ei}$
En tiedä

25. Onko käyttövedessänne todettu laatupoikkeamia seuraavissa veden laatuun vaikuttavissa tekijöissä?

\begin{tabular}{|c|c|c|c|c|c|}
\hline$\square$ Rauta & $\square$ Mangaani & $\square$ Arseeni & $\square$ Sulfaatti & $\square$ Nitraatti & $\square$ Fluoridi \\
\hline$\square$ Kloridi & $\square$ E.coli & $\square$ Koliformiset bakteerit & $\square$ Väri & $\square \mathrm{KMnO}_{4}$-luku & $\square$ Haju \\
\hline Maku & $\square$ Ei & & & & \\
\hline
\end{tabular}

Jos vastasitte johonkin kohtaan myöntävästi, niin milloin laatupoikkeamia on ollut

26. Onko kuivuus ja veden vähentyminen kaivossa aiheuttanut veteen uusia laatuongelmia (mitä ei aikaisemmin ole ollut). Kyllä, mitä?

$\mathrm{Ei}$

27. Oletteko joutuneet kuivuuden ja veden vähyyden takia tekemään jotakin kaivoveden laadun parantamistoimenpiteitä?

Kyllä, mitä 
28. Oletteko joutuneet tekemään veden vähyyden tai laatuongelman poistamiseksi jotakin seuraavista toimenpiteistä?

$\square$ Uuden kaivon rakentaminen

Kaivon ilmastus

Käänteisosmoosin käyttö $\square$ Vanhan kaivon kunnostus

$\square$ Aktiivihiilisuodatus

$\square$ Saostuskemikaalin käyttö $\square$ Pintaveden imeyttäminen kaivon lähelle

$\square$ Aktivoitu alumiinioksidisuodatus

$\square$ Muu toimenpide, mikä

29. Jos toimenpiteitä on tehty, onko käytettävän veden laatu parantunut toimenpiteen vaikutuksesta?

$\square$ Kyllä $\square$ Ei

\section{Tiedot eläinten juomavedestä}

30. Arvioitu eläinten juomaveden tarve

Yhteensä

$1 /$ vrk

1/eläin/vrk

31. Jos vedenlaadussa on ollut ongelmia, onko se vaikuttanut eläinten juomahalukkuuteen?

Kyllä, miten?

$\mathrm{Ei}$

32. Jos vettä ei ole ollut riittävästi, onko sillä ollut vaikutusta tuotantoon?

Kyllä, miten?

$\square \mathrm{Ei}$

33. Onko eläimillä mahdollisuus ulkoiluun?

$\square$ Kyllä $\square$ Ei

34. Minkälaista vettä eläimet juovat ulkona/laitumella ollessaan?

Samaa kuin sisätiloissa $\square$ Muuta, mitä?

\section{Tuotantotilojen pesuvesi}

35. Mitkä tilat pesette ja kuinka usein?

Koko tuotantotila

Karsinat

Käytävät

Lypsyasema

Maitohuone

Muu tuotantotila, mikä

Muut tilat, mitkä

Kertaa viikossa Kertaa kuukaudessa Kertaa vuodessa

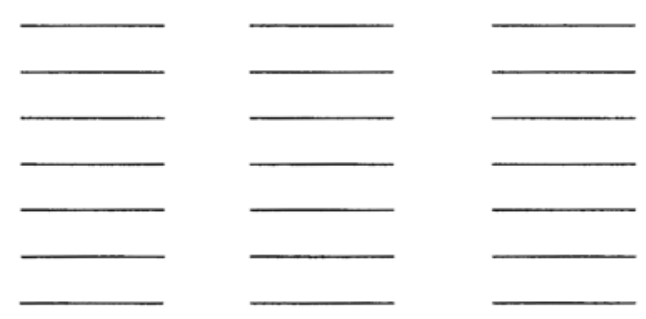

36. Arvioitu vedenkulutus tilojen pesussa

Koko tuotantotila 1/pesukerta Lypsyasema 1/pesukerta Karsinat 1/pesukerta

Maitohuone 1/pesukerta Käytävät 1/pesukerta

37. Onko teillä käytössänne painepesuri tilojen puhdistukseeen?

$\square$ Kylmävesipesuri $\square$ Kuumavesipesuri $\square$ Höyrypesuri

$\square$ Ei. Mitä apuvälineitä käytätte? 
39. Onko vedenkäyttöä jouduttu tehostamaan tai rajoittamaan tilojen pesussa veden vähyyden vuoksi?

Kyllä, miten?

$\mathrm{Ei}$

40. Arvioitu veden kulutus

Maitoputkiston pesussa

1/pesukerta, Maitotankin pesussa

1/pesukerta

41. Käytetäänkö maitoputkiston pesussa varastopesujärjestelmää tai jotain muuta pesuveden kierrätys/vähentämistapaa?

$\square$ Kyllä, mitä

$\square \mathrm{Ei}$

\section{Tilan muu vedenkäyttö}

42. Missä muussa tuotantovaiheessa käytetään vettä?

Kuinka paljon?

1

43. Olisiko tilallanne tarvetta tai halua tehostaa veden käyttöä?

Kyllä, miten?

$\mathrm{Ei}$

Veden hankintaan, käyttöön ja laatuun liittyvät kustannukset

44. Onko veden riittävyyden tai laadun parantamiseksi tehdyistä toimenpiteistä aiheutunut kustannuksia?

Kyllä, arvio kustannuksista €/vuosi $\square \mathrm{Ei}$

45. Jos vettä on jouduttu tuomaan muualta, tästä aiheutuneet kustannukset ovat olleet noin $€ / \mathrm{m}^{3}$

46. Tilojen pesuun liittyvät kustannukset (pesulaitteiden uusiminen, vanhan korjaaminen ym.)

Toimenpide

Kertokaa omia kokemuksianne veden käytöstä, sen tehostamisesta ja riittävyydestä. Mitä mahdollisuuksia tiloilla olisi tehostaa vedenkäyttöään?

Kiitos vastauksistanne! 


\section{MTT:n selvityksiä sarjan Teknologia-teeman julkaisuja}

108 Käyttöveden riittävyys ja laatu maatalouden suurissa tuotantoyksiköissä. Sorvala ym. 34 s. Hinta $15 €$.

107 Maatalousteknologisen tutkimuksen teknologiastrategia. Manni ym. 54 s. Hinta $20 €$.

99 Kotieläintilojen huoltovarmuus. Tertsunen ym. 35 s. (verkkojulkaisu osoitteessa: www.mtt.fi/mtts/pdf/mtts99.pdf).

94 Johtamisella hyvinvointia - Viljelijöiden johtamistoimea käsittelevän internet- sivuston sisällön luominen. Leppälä ym. 28 s. (verkkojulkaisu osoitteessa:

www.mtt.fi/mtts/pdf/mtts94.pdf).

87 Maatilan talouskeskuksen toiminnallinen ja maisemallinen suunnittelu. Tapani Kivinen. 67 s. Hinta $20 €$.

85 Teknologialla tulosta! Toinen teknologiapäivä 11.1.2005. MTT maatalousteknologian tutkimus (Vakola), Vihti. Kallioniemi (toim.). 102 s. (verkkojulkaisu osoitteessa: www.mtt.fi/mtts/pdf/mtts85.pdf).

78 Benefits of agricultural and forestry machinery standardization in Finland. Teye ym., 93 p. Price $20 €$.

72 Jaloittelutarhat - rakenteet ja varusteet. Puumala. 17 s., 7 liitettä. Hinta $15 €$.

50 Maatalouden uusi teknologia - tarkkuutta ja tehokkuutta. Ensimmäiset teknologiapäivät 1.-2.10.2003. Kallioniemi (toim.). 105 s. (verkkojulkaisu osoitteessa: www.mtt.fi /mtts/pdf/mtts50.pdf).

35 Suurten maatalousrakennusten puurunkoratkaisut. Olosuhdemittaukset ja toiminnalliset mallit. Kivinen. 62 s. Hinta $20 €$.

23 Esiselvitys kotieläintalouden ympäristökuormitusta vähentävien menetelmien ja tekniikoiden kustannuksista ja tehokkuudesta. Kallioniemi. 51 s. (verkkojulkaisu osoitteessa: www.mtt.fi/mtts/pdf/mtts23.pdf).

21 Suomalaisen maatalouskoneteollisuuden tulevaisuuden haasteet. Manni \& Riipinen. 208 s. Hinta $25 €$.

18 Sata vuotta tutkittua maataloustekniikkaa. Kallioniemi (toim.). 61 s. Hinta $20 €$.

17 Pihaton lypsyjärjestelmät. Manninen ym. 53 s., 2 liitettä. (verkkojulkaisu osoitteessa: www.mtt.fi/mtts/pdf/mtts17.pdf).

16 Parsinavetan lypsykone: Hankitaanko uusi vai korjataanko vanhaa? Manninen \& Nyman. 10 s. (verkkojulkaisu osoitteessa: www.mtt.fi/mtts/pdf/mtts16.pdf).

5 Riskienhallinnan menetelmät elintarvikeketjussa. Suutarinen \& Mattila. 16 s. (verkkojulkaisu osoitteessa: www.mtt.fi/mtts/pdf/mtts5.pdf). 

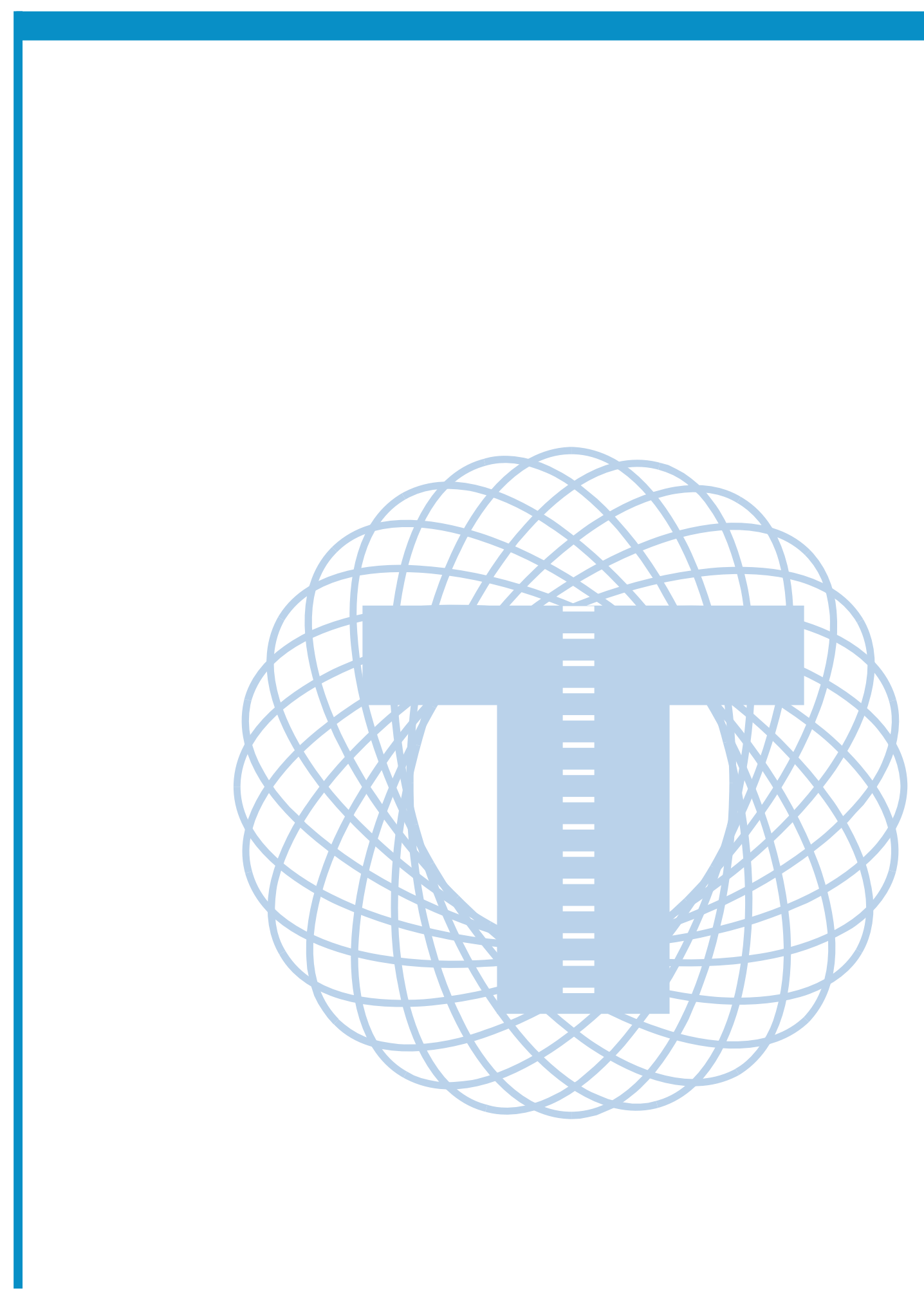